\title{
Počátky univerzitní výuky neklasické archeologie v programových proslovech Jana Kollára a Jana Erazima Vocela (1849-1851)
}

The beginnings of university teaching of non-classical archaeology in the programme speeches of Jan Kollár and Jan Erazim Vocel (1849-1851)

\section{Karel Sklenář}

\begin{abstract}
Abstrakt
Před 170 lety vznikly první středoevropské univerzitní katedry zaměřené výslovně na neklasickou archeologii: ve Vídni se stal profesorem roku 1849 Jan Kollár, v Praze 1850 Jan Erazim Vocel. Náplň a zaměření jejich výuky v tomto období dokládají nejlépe úvodní a závěrečné proslovy, dochované v rukopisné i tištěné formě; zřetelně je z nich patrný rozdíl mezi romantickým přístupem Kollárovým, který především nekriticky hledal stopy domnělého původního slovanského osídlení Evropy (hlavně v Itálii), a Vocelovým, jenž už rozlišoval mezi archeologií „pohanskou“ a „křestanskou“ (pravěkou a středověkou) a svým pojetím oboru směřoval už k pozitivismu. Součástí článku jsou texty těchto projevů.
\end{abstract}

\begin{abstract}
The first Central European university chairs focused specifically on non-classical archaeology were established 170 years ago: Jan Kollár became a professor in Vienna in 1849, Jan Erazim Vocel in Prague in 1850. The content and focus of their teaching in this period is best evidenced by introductory and concluding speeches, preserved in manuscript and printed form; above all, they clearly demonstrate the difference between Kollár's Romantic approach, which for the most part uncritically sought traces of the supposed original Slavic settlement in Europe (mainly in Italy), and Vocel's, which already distinguished between "pagan" and "Christian" (prehistoric and medieval) archaeology and with his concept of the field was already heading for Positivism. The article includes the texts of these speeches.
\end{abstract}

Klíčová slova: neklasická archeologie - univerzitní výuka - Jan Kollár - Jan Erazim Vocel Keywords: non-classical archaeology - university instruction - Jan Kollár - Jan Erazim Vocel

DOI: $10.14712 / 25707213.2021 .3$

Jedním z důvodů, proč se vznik neklasické archeologie jako řádného vědního oboru ve srovnání s mnohými, zejména př́rodovědnými obory opozdil, byla její absence na vysokých školách, propojující se s amatérskou praxí do bludného kruhu. Př́íkladem může být starobylá pražská univerzita Karlo-Ferdinandova a univerzity v rakouské ř́iši obecně: o klasických starožitnostech (Alterthumskunde) - třebaže pod tímto pojmem šlo hlavně o četbu antických autorů a popisy řeckého a římského umění - se přednášelo místy už v 18. století v rámci pomocných historických věd (Lipsko, Göttingen, Krakov, od r. 1784 Praha), ale jejich učitelé (v Praze první profesor Franz Anton Steinsky, po něm Jan Nepomuk Helbling z Hirzenfeldu) nevěděli prakticky nic o klasické archeologii v dnešním smyslu a tím spíše ne o archeologii neklasické Evropy, tehdy obvykle označované jako „pohanská“. U ní záleželo na osobním zájmu nečetných jednotlivců, kteří ji začali do svých výkladů uvádět v severní Evropě. Středoevropští studenti se o ní doslechli poprvé po roce 1816 na filozofické fakultě univerzity ve slezské, tehdy pruské Vratislavi (Breslau), kdy se zde pro pomocné vědy historické a německé „starožitnosti“ (v tehdejším širokém smyslu) habilitoval aktivní archeolog Johann Gustav Gottlieb Büsching (1783-1829); po jeho smrti ale tato krátká éra zase skončila.

Souběžně s Büschingovou činností se však v Nizozemí podařilo poprvé, byt' také nakrátko, zato nadlouho naposledy oficiálně zřídit (mimořádnou) 
profesuru archeologie nejen klasické, ale výslovně i domácí, když holandský král Vilém I. dne 13. 6. 1818 jmenoval do této funkce Caspara Jacoba Christiaana Reuvense (1793-1835), dotud profesora latiny a řečtiny. Také Reuvens prováděl praktickou terénní archeologii, zejména první profesionální vykopávky v Nizozemí na pozůstatcích římskoprovinciální osady Forum Hadriani (Voorburg-Arentsburg u Haagu) v letech 1827-33; v Leidenu zřídil i Říšské (později Národní) muzeum starožitností. Také tady ale jeho smrtí katedra zanikla. ${ }^{1}$

To byly první a ojedinělé pokusy, předcházející první vlně nástupu neklasické-domácí (pravěké a raně středověké) archeologie na evropské univerzity, jež přišla v polovině 19 . století. Univerzity habsburské monarchie nepatřily v Evropě k odborné špičce; tím spíše se zdá být pozoruhodné, že tato vlna začala právě na nich - okolnosti, jež to umožnily, však s vědou nesouvisely. Stručně řečeno: vláda, jež v březnu 1849 povolala z Pešti do Vídně slovenského protestantského duchovního Jana Kollára jako důvěrníka v záležitostech slovanských národností v Uhrách, rozhodla odměnit stárnoucího básníka a známého nadšence pro „slovanské starožitnosti“ za jeho rady i za loajalitu a nedávné věznění v Pešti během právě přemožené mad'arské revoluce tím, že jej v dubnu jmenovala mimořádným profesorem tohoto oboru na vídeňské univerzitě. ${ }^{2}$

Význam tohoto kroku pro budoucnost nebyl vcelku vědecký, zato ale praktický: když totiž Vídeň jako metropole a sídlo panovníka takovou katedru získala, nebránilo už celkem nic zřízení vyučovacího místa pro tento dosud neuplatněný a tedy poněkud sporný obor na jiné univerzitě v monarchii. Celkem logicky přišla na řadu Praha, která byla v té době nejživějším centrem ř́šse v oboru neklasické, domácí archeologie díky Českému (Národnímu) muzeu a jeho Archeologickému sboru (od 1841), ${ }^{3}$ jehož vůdčím duchem byl nejpřednější český archeolog té doby Jan Erazim Vocel. Je zajímavé, že také Vocelův pokus o profesuru archeologie podporovalo spíše vídeňské ministerstvo kultu a vyučování než pražská univerzita sama a hlavně díky tamním příznivcům se Vocel stal 7. 2. 1850 mimořádným profesorem archeologie Karlo-Ferdinandovy univerzity.

Tento př́spěvek nemá za úkol analyzovat obě profesury, ale zpřístupnit pozoruhodné dokumenty, z nichž jasně vyplývá nejen jejich věcná náplň, ale zejména odlišná povaha a zaměření jejich nositelů, jejich program, názory a snahy. Jde o dochované texty úvodních a závěrečných přednášek, jimiž Kollár

1 Ke zmíněným počátkům více Sklenár $1981 b$; týż 1983a, 82-85; týż 1983b, 59-60; týž 2020 s bibl.

2 Ke Kollárově profesuře kromě výše citované literatury Karásek 1893, Skutil 1951, Zagiba 1965.

3 Sklenár 1968; týž 2014, 32 a násl. pravidelně zahajoval a končil jednotlivé semestry, zatímco z Vocelovy činnosti se dochovaly jen programní přednášky ze samého začátku jeho pedagogické činnosti. V každém případě jde o zajímavé a $\mathrm{z}$ větší části dosud neznámé doklady myšlenkové i praktické podoby výuky archeologie v jejích nejranějších počátcích.

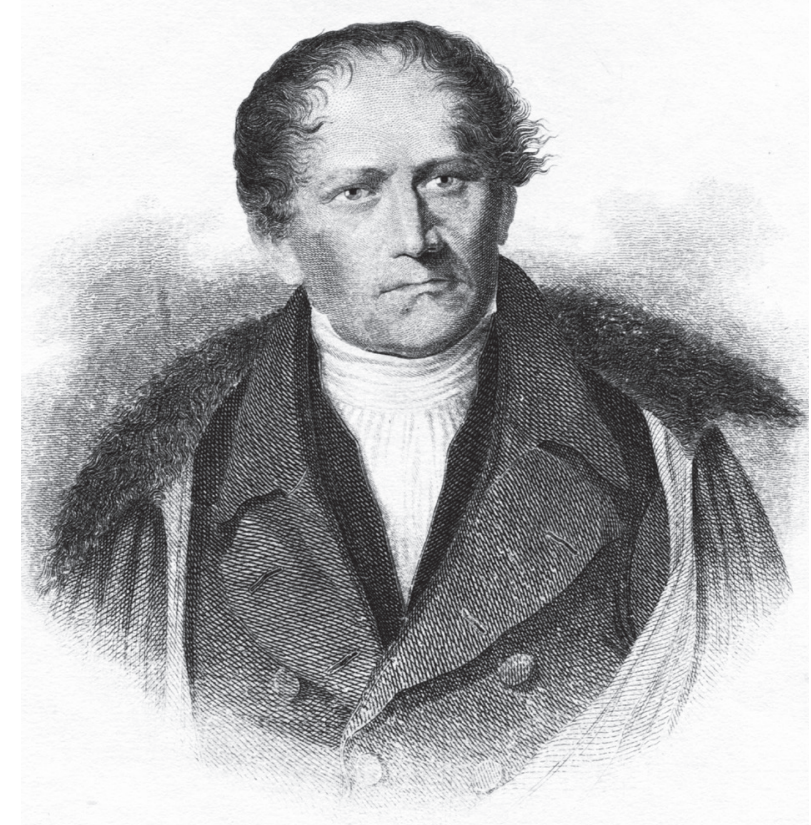

Obr. 1. Jan Kollár (rytina podle kresby J. Vilíma, asi kolem roku 1850). - Fig. 1. Jan Kollár (engraving based on the drawing by J. Vilím, perhaps around 1850).

Jan/Ján Kollár (1793-1852), ${ }^{4}$ evangelický kazatel, básník, filolog a propagátor slovanské jednoty pocházející ze Slovenska, vyškolený v Německu, působící v mad'arské Pešti a píšící česky je pozoruhodnou postavou národního obrození: v mládí se proslavil jako básník Slávy dcery, vlastní slávu i dílo postupně rozmělňoval přechýlením k filologicko-archeologickým fantaziím a zemřel jako osobnost ze setrvačnosti vážená pro své minulé zásluhy. Jeho profesura byla spíše jakýmsi čestným důchodem, protože o vědeckosti Kollárových domněnek a spisů neměli vídeňští ani pražští odborníci žádné iluze.

Kollár začal (v budově akademického gymnasia, kde probíhaly všechny jeho přednášky, zhruba pět hodin týdně) vyučovat dne 21. 5. 1849, měsíc poté, co byla jeho profesura (29.4.) úředně schválena. (Toho roku mu také pražská univerzita udělila čestný doktorát.) Jeho první zahajovací řeč se dochovala pouze v rukopise (Kollár 1849a, viz zde př́lohu 1). Prvním plným semestrem Kollárovy výuky byl zimní semestr

4 O něm nověji Otruba 1993 se soupisem dosavadní literatury. 
1849/50; jeho vstupní proslov z 5. 11. 1849 otiskly Havlíčkovy Národní noviny, bohužel neúplně a místy zkresleně (Kollár 1849b, viz zde př́lohu 2 podle rukopisu). Také závěrečná řeč tohoto semestru je dochována v rukopise (príloha 3), rovněž tak i závěr letního semestru 1850 (príloha 4) a vstupní řeč zimního semestru 1850/51 (príloha 5). Poslední z těchto dokumentů je řeč při zahájení zimního semestru 1851/52, přednesená 15. 10. 1851 (príloha 6); ta se nedochovala v rukopise, byla však otištěna ve vídeňském českém časopise Vesna (Kollár 1851) - prý na přání posluchačů. Tomu lze věřit, protože podle dochovaných svědectví (Karásek 1893, 67) byl Kollár jako učitel pro svůj přátelský přístup ke studentům i zaujaté přednášení oblíben, i když on sám si stěžoval na nedostatek zájmu (posluchačů míval pět až osm). „Trpce se musil p. K. vyznati strany navštěvování přednášek, že není ještě doba, kdež by naši synové do chrámu slovanské vzájemnosti dychtivě chodili, obdivujíce se pozůstatkům bývalé slávy a velikosti národní umy a vzdělanosti." (Vesna 1851, 336.)

S použitím dobových seznamů přednášek (Karásek 1893, 67-68; Zagiba 1965, 148), lze Kollárovo působení na vídeňské filozofické fakultě rekonstruovat takto (ZS, LS = zimní a letní semestr):

$\begin{array}{ll}\text { LS 1849 } & \text { /zahájil později, přednášel } \\ \text { o Etruscích/ } \\ \text { ZS 1849/50 } & \text { Ueber Umbrische Alterthümer und } \\ & \text { Inschriften, insbesondere über die Igu- } \\ & \text { vinischen Tafeln, in Beziehung zu dem } \\ & \text { Altslovenischen }\end{array}$

LS 1850 pokračování téže přednášky

ZS 1850/51 Ueber slavische Alterthümer in Norddeutschland, besonders über die Rhetra-Prilwitzer Götzen

LS 1851 pokračování téže přednášky

ZS 1851/52 Ueber den zweiten mythologisch-astronomischen Theil der RheträischenAlterthümer oder über den Zodiakus der alten Slaven, verglichen mit dem indisch-ägyptischen Thierkreis, und über die Aechtheit der zu Rhetra-Prilwitz ausgegrabenen Alterthümer.

Nedokončeno - před koncem semestru Kollár ve Vídni zemřel./

Jistě je pozoruhodné, že to byla právě slovanská archeologie, která získala první archeologickou vysokoškolskou profesuru v rakouské ř́iši. $\mathrm{K}$ tomu je ale nutno podotknout, že jednak byl pojem „starožitností“ stále ještě tradičně chápán především ve smyslu historicko-filologickém, jak svědčí Slovanské starožitnosti Šafaříkovy (v nichž měl Kollár pokračovat), na druhé straně si Kollár svoji „národní starotinovědu“ zúžil v podstatě na dvě témata, jimž v posledních letech života obsesivně propadl a jež neměla pro vědu žádný význam: dokazování slovanskosti
Etrusků a vůbec osídlení předklasické Itálie ${ }^{5}$ a pravosti „retranských idolů“, falešných sošek s fiktivními slovanskými nápisy z Prillwitz v Meklenbursku (domnělé raně historické slovanské Retry).

Základní smysl veškerého Kollárova starožitnického snažení postihují jeho slova: „skrze hroby jako skrze okna spatřujeme zde bohatý znamenitý život celých rodin, krajin a říší; naše ucho slyší zde zvuky a slova naší mateřské řeči, jako ona před tisíci, anobrž dvěma, třemi tisíci lety zněla; naše oko vidí zde předhistorické zbořené prŕíbytky, chrámy, bohy, nádoby, zbroje, peníze, umělecká díla a jiné památky rukami našich otců a praotců udělané, těch otců a předků, které pyšní Řekové co barbary považovali a opovrhovali. Zde se samovidně přesvědčujeme o tom, že naši předkové ve mnohém ohledu právě učitelé pyšných Helenů byli“. S určitým smutkem přitom pozorujeme, jak se u Kollára neustálé zapř́ísahání vysokou kritičností a odmítání s výmyslů přesahujících holá fakta druží například s „objevováním“ slovanských zeměpisných jmen v Itálii pomocí až komického „bakalářského“ etymologizování.

Jestliže Kollárova činnost nepřinesla skutečné archeologii téměř nic, Vocelova práce znamená pravý opak. Jan Erazim Vocel (1802-1871), ${ }^{6}$ př́tel Františka Palackého, původně známý jako básník a spisovatel, se stal archeologem až ve 40 . letech vlastně z nutnosti, když jej Palacký vyzval ujmout se redakce Časopisu Českého musea (tehdy nejvýznamnějšího českého odborného časopisu) a jednatelské funkce v Archeologickém sboru.

Důležitější než odbornost byla však pro úspěch záměru, na němž Vocel začal pracovat hned po ustálení politických poměrů („normalizaci“) v říši, jiná okolnost: Vocel tehdy patřil - spolu s historikem Václavem Vladivojem Tomkem i jinými - k tzv. české „vládní straně“ podporovatelů normalizace, jíž v čele stál sám ministr kultu a vyučování hrabě Lev Leopold Thun-Hohenstein a která se snažila právě tímto postojem pomoci české národní věci ohrožené nástupem absolutismu. Díky tomu a díky nedávnému rozhodnutí, že členové uznávaných vědeckých společností ( $v$ př́padě obou jmenovaných to byla Královská česká společnost nauk) jsou oprávněni přednášet na rakouských univerzitách, se na pražské univerzitě Tomek stal profesorem historie a Vocela - přes původní odpor filozofické fakulty, žádající přednášet o obecné archeologii a nejen o české - jmenoval císař na návrh ministra 7. února 1850 mimořádným profesorem české archeologie

\footnotetext{
5 O Kollárově vztahu k archeologii v užším smyslu Skutil 1944-48.

6 Sklenář 1971, týž 1981a; týž 2005, 625-626; Benda 1980.
} 
a dějin umění. ${ }^{7}$ Přesto ale pak v roce 1853 byl název Vocelovy profesury změněn z české archeologie na obecnou, snad jako důvod ke zvýšení platu, a když se v r. 1862 přeměnila na řádnou (ačkoli to původně ministerstvo odmítalo, že u malých oborů to není obvyklé), zněla na archeologii, dějiny umění a českou literaturu. V tom se odráží postupné rozšiřování Vocelovy oborové působnosti - $\mathrm{k}$ původní archeologii (jež zahrnovala pravěk a středověk, ten včetně dějin umění) přibíral z vlastní i úřední vůle klasickou archeologii, estetiku, právní historii, dějiny české literatury či paleografii.

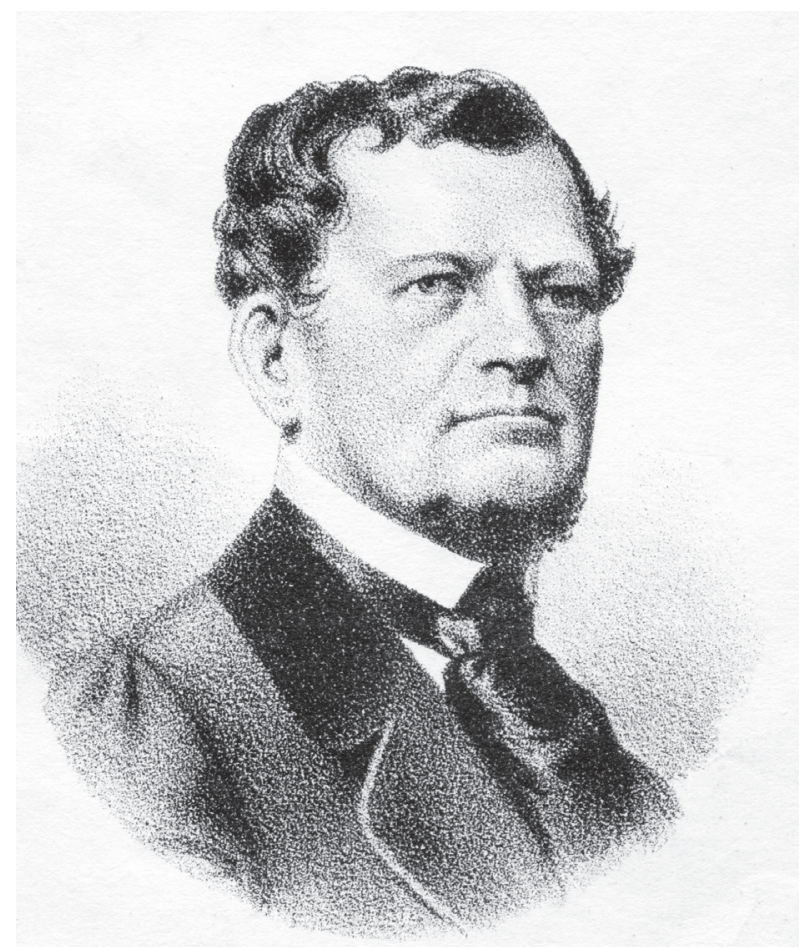

Obr. 2. Jan Erazim Vocel (litografie podle kresby K. Maixnera ze 60. let 19. století). - Fig. 2. Jan Erazim Vocel / Johann Erasmus Wocel (lithograph based on the drawing by K. Maixner from the 1860s).

(Celkem neznámým zůstává fakt, že Vocel nebyl jediným zájemcem o archeologickou profesuru: souběžně o ní uvažoval i jeho spolupracovník v Národním muzeu - první kustos osamostatněné archeologické sbírky - a konkurent v záměru vést vznikající českou archeologii, Josef Vojtěch Hellich. Oblíbený maliřr, známý už svými portréty např. Palackého či Boženy Němcové, se rovněž činně zúčastnil událostí roku 1848, ale na rozdíl od Vocela prováděl až ponižující „sebekritiku“, aby se mohl ucházet o místo profesora „historie na archeologickém základě“, jež mělo být zřízeno na vídeňské akademii výtvarných

7 O odporu fakulty Národní noviny 2, č. 266, 1040. umění. ${ }^{8}$ Důvěru ministra Thuna a policie a tedy ani vytoužené místo však nezískal.)

Okolnosti vzniku i další osudy Vocelova univerzitního působení v tomto i jiných více či méně příbuzných oborech jsou podrobně popsány jinde, ${ }^{9}$ proto je zde přehlédněme jen velmi stručně.

Poté, co pro úřední potřebu vypracoval německy psaný program svých přednášek (viz př́lohu 7), zahájil Vocel svoji učitelskou činnost v letním semestru 1850 (10. dubna) v Klementinu jednosemestrovou přednáškou „Česká archeologie pohanské doby“: „podav stručný a jasný přehled dějin politických a vzdělanosti národův předslovanských, ve vlasti naší bydlících, obšírněji pak přednesl starožitnosti doby slovanskopohanské, od r. 450 do konce 9. století sáhající. Každého čtvrtku scházívalo se posluchačstvo v národním Museum, kde p. Vocel starožitné ostatky doby přednešené ukazoval a vysvětloval." (7. Z. 1850.) První čtení bylo zmíněného dne věnováno českému úvodnímu proslovu, který byl poté s malými odchylkami otištěn v Časopise Národního muzea (ke srovnání obou textů viz př́lohu 8).

V zimním semestru 1850-51 pak Vocel přednášel o „uměleckých starožitnostech křest'anského středověku" (první z přednášek tohoto typu, jež se vzdor původnímu širokému záměru nakonec soustředily na středověké - románské a gotické, romantismem nejvýše ceněné umění), v čemž pokračoval i v letním semestru 1851. Také tato přednáška byla opatřena programovým úvodem (viz prílohu 9), tentokrát publikovaným v podobě brožurky (Wocel 1850b; k obsahu týž 1852). V zimním semestru 1851-52 pak následoval opět „Pravěk české země, památkami archeologickými a historickými osvětlený“, atd.

Tyto texty zde v př́loze reprodukované doplňuje ještě nedatovaný Vocelův rukopis, představující jakýsi koncept úvodu k přednáškám o „pohanském věku" (je tak i označen a obsahové shody s Úvodem $\mathrm{v}$ př́loze 8 svědčí, že byl přípravou $\mathrm{k}$ němu). ${ }^{10} \mathrm{Zdů}$ razňuje tytéž prameny - národní pověsti, jazykozpyt a „hmotné ostatky dávnověkosti“, přitom ale nejužší spojení s historií („archaeolog v tom smyslu musí být historikem, historik však nikoli archaeologem“) a s podporou přírodních věd. „Věda tato přispívá $\mathrm{k}$ uvědomění a ušlechtění mladého pokolení čecho-

8 Dopis hr. L. Thunovi 21. 3. 1850 (Literární archiv Památníku národního písemnictví, Praha, fond J. V. Hellich). Více k tomu Sklenár $1980,156-158,215-216$.

9 Sklenár 1981a, 170-224; týž 1981b. K Vocelovu univerzitnímu působení dále Skutil 1947, Šimek 1950, 170-224, Salač 2006, v rámci dějin fakulty Kazbunda 1965, 44, 156-169; Petráň 1983, 151, 153-7, 162-3, 178-9, 187, 190, 216, 243.

10 Rukopis bez titulu a data; Státní okresní archiv Kutná Hora, fond J. E. Vocel. Text reprodukován in Sklenár 1981a, 390-391. 
slovenského, jehož úlohou jest, aby vytrvale pracujíc, vědeckou i mravní jadrností svou národnost českou před světem $\mathrm{k}$ vyšší vážnosti a důstojnosti povzneslo."

Zmíněná první přednáška v dubnu $1850^{11}$ měla na 60 posluchačů, nejspíše kvưli novosti námětu; později zájem klesal a nikdy už tohoto čísla nedosáhl. Nižší byl rovněž zájem o první přednášku o archeologii křestanského středověku (12 zapsaných posluchačů; víme však, že na přednášky chodila i řada hostí). Nešlo ale samozřejmě o masovou ani o povinnou záležitost, přicházeli sem jen skuteční zájemci. I tak prošlo Vocelovými přednáškami mnoho desítek studentů, mezi nimi budoucí archeologové a lidé s oborem spojení (J. K. Hraše, J. O. Miltner a J. B. Miltner, G. C. Laube, J. Hlavatý, K. Špaček, V. Křížek, F. J. Zoubek, K. Roth, A. Tille, J. Orth, B. Jelínek, J. Hladík, J. L. Píč aj.), budoucí historikové (Lepař, Tieftrunk, Tonner, Lippert, Perwolf, Lehner, Tadra, Sedláček, Kalousek, Peisker, Winter, Goll) a na druhé straně spisovatelé a básníci - Neruda, Solc, Čech, Štolba. - Naproti tomu z posluchačů Kollárových přednášek se do dějin české archeologie nezapsal nikdo.

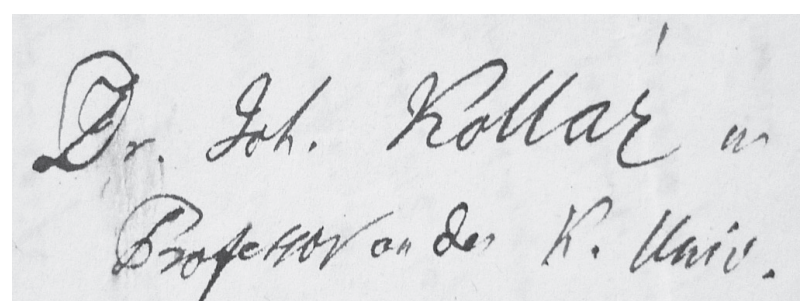

Obr. 3. Podpis Jana Kollára jako profesora vídeňské univerzity. - Fig. 3. Signature of Jan Kollár as a professor at the University of Vienna.

Porovnání nástupních řečí a úvodů $\mathrm{k}$ přednáškám může být zajímavé. Povšimneme si zásadních rozdílů mezi přístupem Kollárovým a Vocelovým. $\mathrm{V}$ textech jich obou, $\mathrm{v}$ dobově oblíbené nadšeně nabádavé vlastenecké dikci se odráží jejich minulost národních básníků - v obsahu je ovšem rozdíl: Kollár zůstal básníkem i ve vědě, kterou naplnil romantickým nadšením bez potřebné kritičnosti (a těmito svými produkty později doplňoval svou starší poezii - Kollár 1832), naopak Vocel jevil už v poezii učenecké tendence a ty u něj nyní zcela převládly bez ohledu na častá poetická vyjádření. Vocel pojal svůj programový vstupní proslov (sepsaný už předem, v listopadu 1849) velmi pečlivě, na rozdíl od Kollára spíše věcně než proklamativně. Zdůraznil nicméně, že jde o archeologii českou, která na

11 Viz referát o ní pod značkou $\Delta$, Bohemia 23, 1850, č. 57 (11. 4.). české univerzitě dosud přednášena nebyla, ačkoli pro národní uvědomění má nemalý význam: „Historická důstojnost národa žádá, aby národ poznal sám sebe." Národ nepředstavují jen současné generace, je to historické společenství všech generací a sláva pokolení minulých posiluje národní hrdost dnešních Čechů (viz př́lohu 8). Archeologie ,jest nejmladší věda, jižto duch času zplodil, jelikož právě ve hnutí národním nynějšího věku původ a počátek svůj béře." Zatímco tedy Kollár zaměřuje svoji archeologii $\mathrm{k}$ všeslovanským cílům a oslavě (domnělého) klíčového postavení Slovanstva u základů evropské civilizace, Vocel správně vidí archeologii jako produkt novodobého nacionalismu a nástroj národního hnutí.

Rozdíly jsou patrné i v definici vlastního oboru. Kollár, který v ojedinělém exkurzu své řeči z podzimu 1849 (př́loha 2) shromáždil a definoval všechny myslitelné české ekvivalenty latinských a německých označení oboru a jeho nositelů, popsal archeologii jako tradiční širokou disciplinu "starožitností “: „Starověda - Archaeologia, něm. Alterthumswissenschaft, t. j. věda starého času a jeho obsahu vůbec, $v$ př́sný vědecký soustav uvedená, zde theorie i praxis, čas i věci v něm, forma i látka, literní i umělecké plody, duchovní i tělesný život, k. p. řeč, báje, pověsti, bohosloví, svátky, oběti, obřady, pak hmotné pozůstatky, rumy, zbořeniny, zdi, hroby, nápisy, obrazy, sochy, řezby, litiny a t. d." Na více místech zdůrazňuje, ovlivněn klasickou archeologií, že „ovšem při všech starožitnostech jsou a zůstanou nápisové a literaturní zlomkové veždy nejdůležitějš́í a nejpamátnější." Epigrafické památky ,jsou jazykem archaeologie“, nádoba či jiný předmět bez nápisu „jest jako cele němý člověk, byt' pak tento byl sebe krásnějším, my jemu nerozumíme“.

Vocel naopak z pohledu domácího materiálu zdůrazňuje, že v „nejdávnější př́edkřestanské době vlasti naší archeologické zpytování zaujímá přední místo, kdežto dějepis do zadu ustupuje“, a požaduje bezprostřední styk studentů s nálezovým materiálem z muzejních sbírek. Archeologii definuje poněkud jinak už v předběžném programu (př́loha 7): jejím smyslem a cílem je „das Leben des böhm. Volkes in seiner Urzeit, /.../ mit Hilfe alter Kunst- und Kulturdenkmale zu erforschen und darzustellen. Die böhmische Alterthumskunde umfasst allerdings bloss ein Aggregat empirischer Erkenntnisse, erlangt aber durch die systematische Anwendung des zur Realisierung des obersten Zweckes dienenden Material einen wissenschaftlichen Charakter." Za zvláštní úkol označuje zásadní potřebu, „mit Hilfe der historischen Kritik, der vergleichenden Sprachen- und Völkerkunde" najít v archeologických památkách „eine charakterisierende Unterscheidung zwischen 

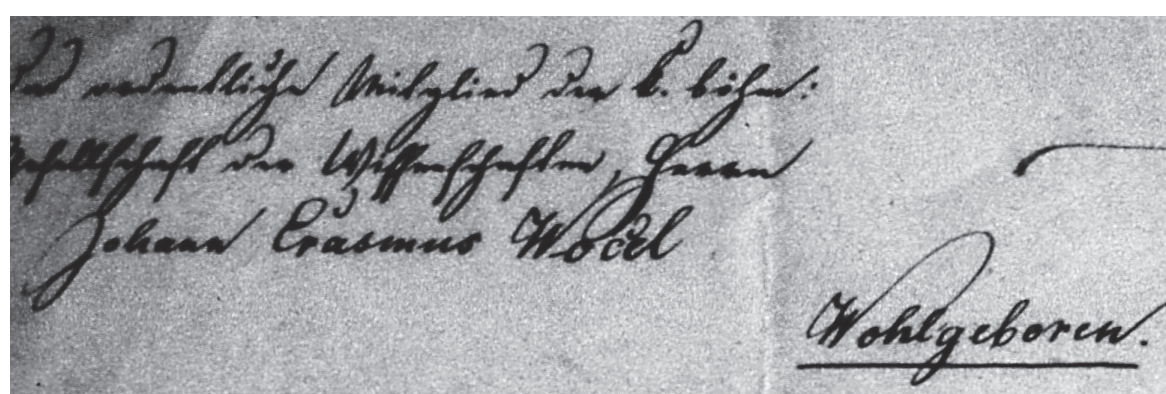

E. $2 / 1$.

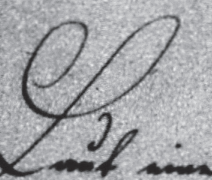

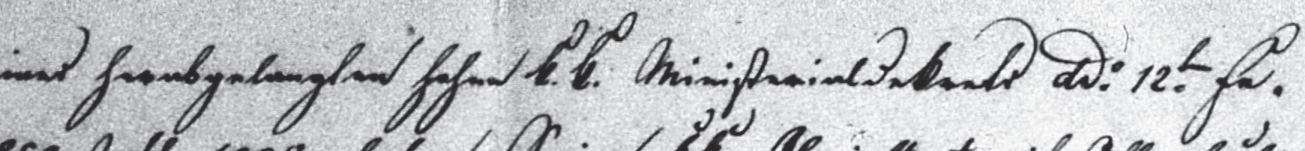

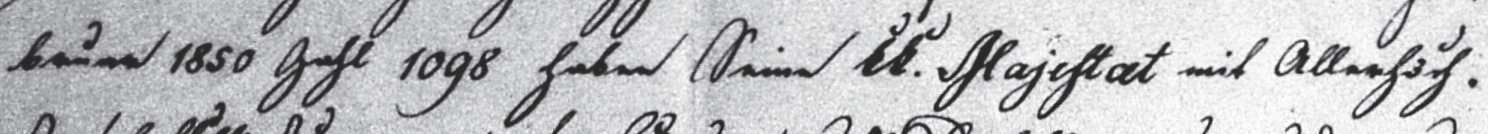

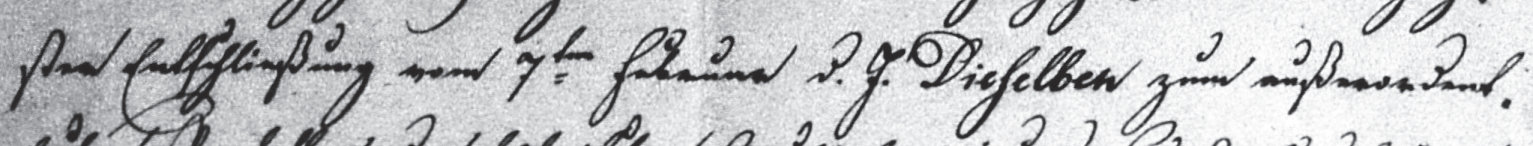

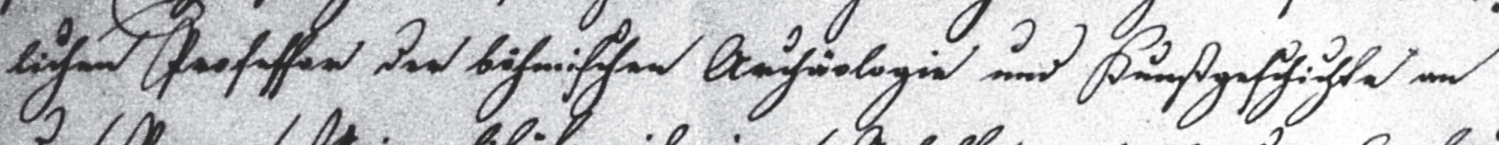

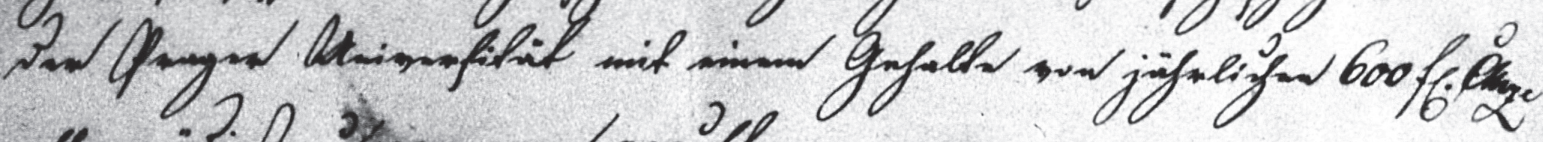

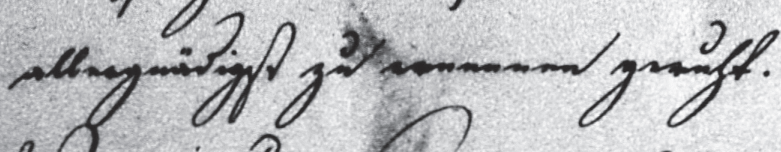

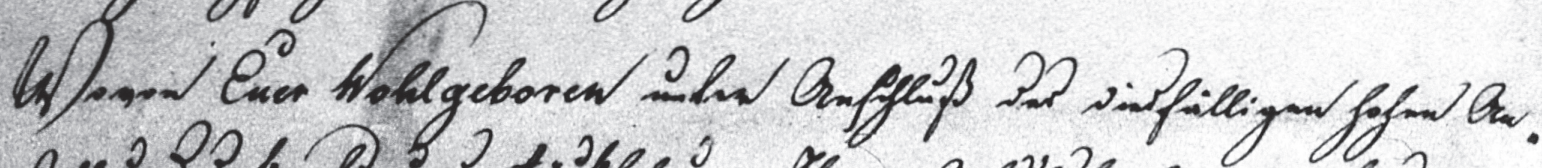

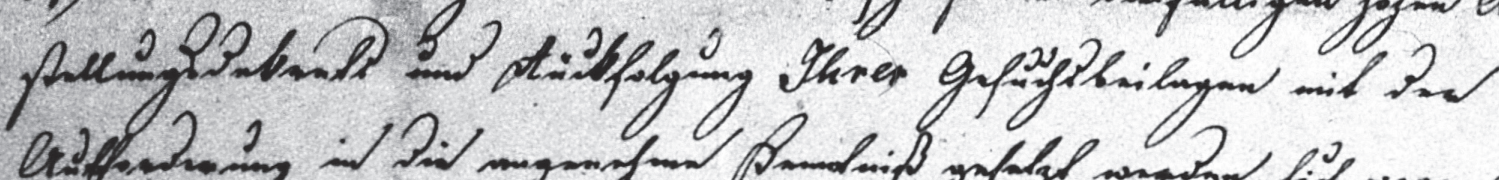

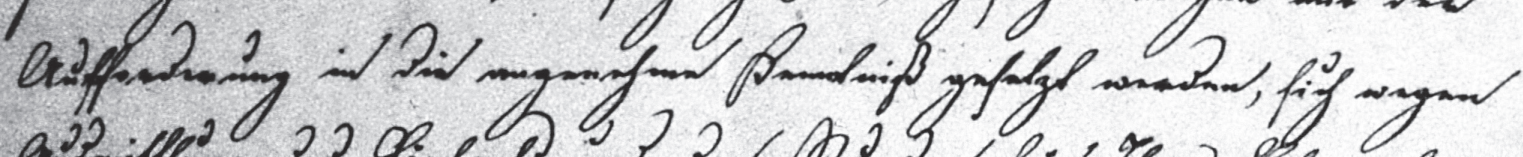

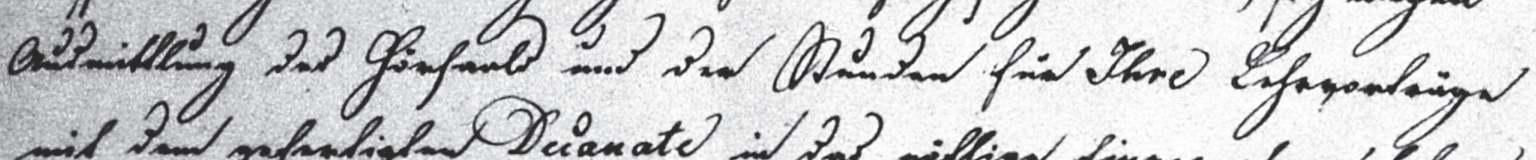

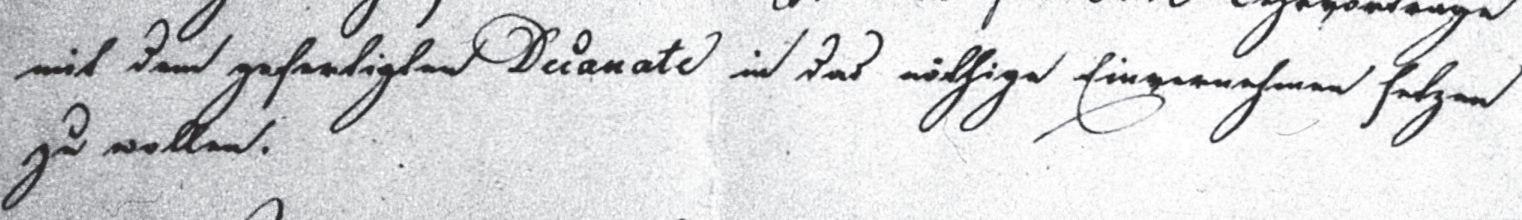

Q.).

$$
\text { Pay, and at: fátina } 1850 \text {. }
$$

Obr. 4. Oznámení J. E. Vocelovi o jmenování profesorem Karlo-Ferdinandovy univerzity v Praze, 27. 2. 1850 (Státní okresní archiv, Kutná Hora, fond J. E. Vocel) . - Fig. 4. Announcement to J. E. Vocel on his appointment as a professor at Charles-Ferdinand University in Prague, 27 February 1850 (State District Archive, Kutná Hora, J. E. Vocel collection). 
keltischen, germanischen und slawischen Alterthümern in Böhmen".

Vocel ovšem neopomněl zdůraznit, že $\mathrm{v}$ tomto případě nejde o dějiny politické či vojenské, ale kulturní, neméně důležité. Donedávna se věda zajímala jen o památky antického starověku, kdežto o slovanských nevěděla takřka nic; hmotné památky a lidová tvorba jsou pramenem schopným vyplnit prázdno mezi historií antickou a středověkou - v tomto vymezení se projevuje romantický duch, zároveň ale odkazy na pomoc dalších (přírodo)vědních odvětví a snaha o co nejširší pramennou základnu ukazuje už nový směr k budoucímu pozitivismu. Romanticko-poetická závěrečná definice české archeologie na této skutečnosti nic nemění.

$\mathrm{V}$ jiném rukopisném fragmentu, dochovaném $\mathrm{v}$ jeho pozůstalosti, Vocel definuje poměr obou svých hlavních oborů: „Kdežto se /.../ archeologie pohanské doby ponejvíce kritickým děje- a národopisným bádáním obírá, leží hlavní váha archeologie středověku českého $\mathrm{v}$ uměleckém zpytování a uvažování. Pročež byt' i oba oddíly k jednomu cíli, totiž k objevení života národního dávných Čechův směřovaly, každý z nich zvláštními zákony veden jsa, jinou cestou k společnému cíli se béře." Takto byl vlastně položen základ $\mathrm{k}$ dichotomii typické pro českou archeologii budoucnosti: zatímco archeologie v užším smyslu se soustředila na pravěk a raný středověk, na prehistorii a protohistorii (byla také až do poloviny 20 . století obvykle označována synonymem „prehistorie“), archeologie historická (vrcholně středověká a mladší) musela po Vocelovi čekat ještě dalších sto let na své docenění.

Nikoli okrajová byla otázka vyučovacího jazyka, $\mathrm{v}$ té době sledovaná. $\mathrm{V}$ tom směru prošly Kollárovy přednášky zajímavým vývojem.

"Česká strana" na vídeňském ministerstvu kultu a vyučování, $\mathrm{k}$ níž patřil i ministr Thun, byla poněkud překvapena, že Kollár začal přednášet německy. On sám se za to ve vstupním proslovu omlouval, že sám sice v archeologii myslí i píše česky, ale (kromě respektu k postavení němčiny jako učeneckého jazy-

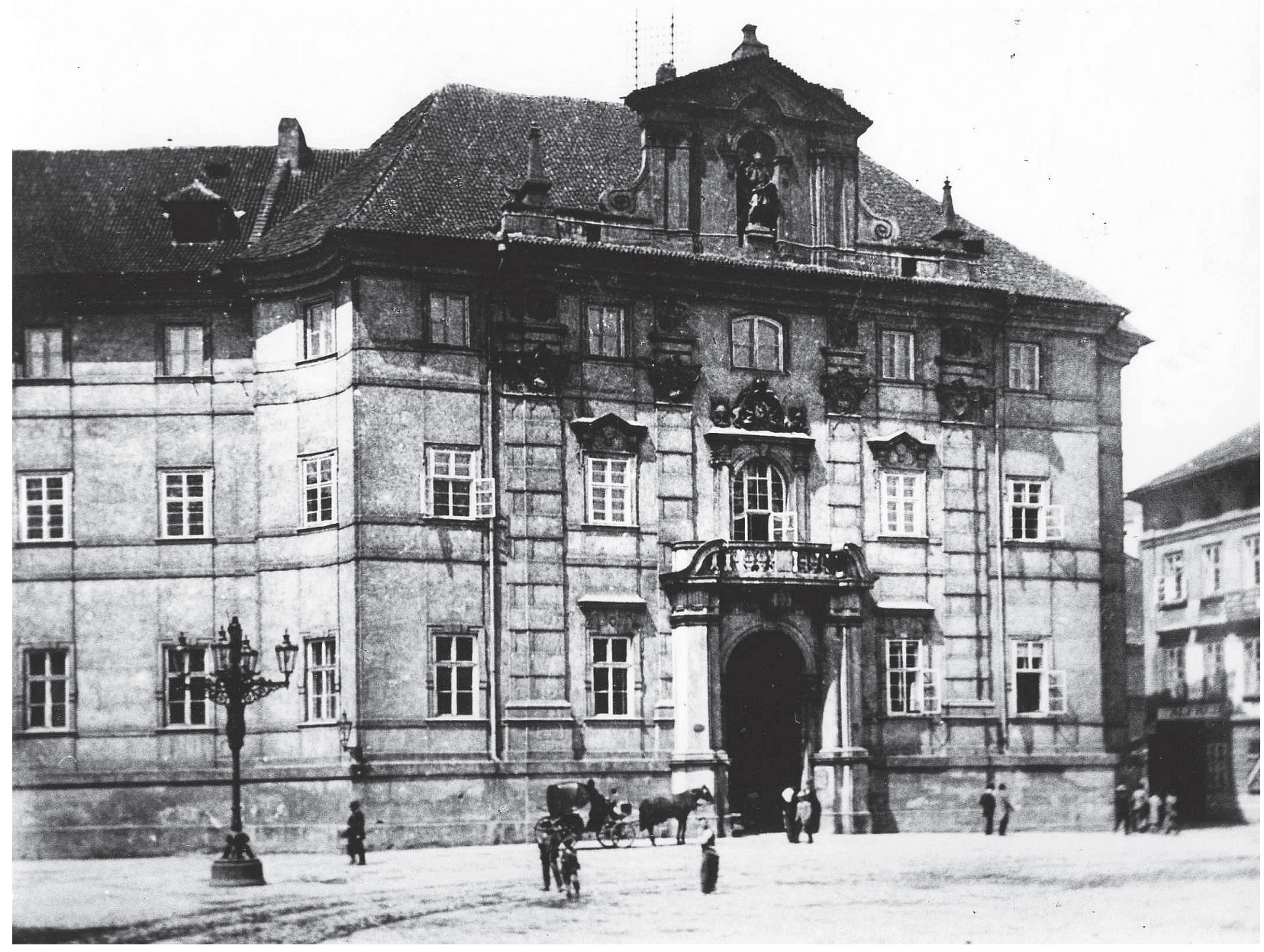

Obr. 5. Východní křídlo Klementina (Praha-Staré Město, Mariánské nám.) v době, kdy zde byly posluchárny filozofické fakulty Karlo-Ferdinandovy univerzity. - Fig. 5. East wing of the Klementinum (Prague-Old Town, Mariánské nám.) at the time when there were lecture halls of the Faculty of Arts of Charles-Ferdinand University. 
ka ve střední Evropě a ovšem ve Vídni) předpokládá, že jeho čtení budou navštěvovat vídeňští Němci; zjistil však brzy, „že téměř všichni posluchači těchto starožitností Slované byli, obzvláště k nářečí českoslovanskému přináležející", takže už v dalším semestru - navíc na výslovné přání ministra Thuna - vítal posluchače „V naší milé národní slavočeské řeči“ (Kollár 1849b). „Chcit' zajisté, aby Slavjanstvo vůbec alespoň jednu katedru a profesuru čistoslavjanskou mělo, kde by i předmět i jazyk, i věc i řeč slavonárodní byly." Jenže učinil zkušenost opačnou, že i slovanští posluchači přes počáteční snahu nakonec odpadali, protože jeho složité výklady v češtině nedokázali sledovat; proto se na počátku nového semestru říjnu 1850 zase vrátil k němčině jako osvědčenému prostředku dorozumění Slovanů. 12

Vocel v Praze postupoval opačně: jako jeden z prvních využil nedávné zrovnoprávnění jazyků na univerzitě (důsledek roku 1848) a začal hned přednášet česky, až od roku 1853 začleňoval do svého programu i přednášky německé, patrně aby přitáhl další studenty, kterých ani v Praze mnoho nebylo. (Navíc, pokud víme, Kollár jako celoživotní evangelický kazatel byl zkušený a oblíbený řečník, záměrně se snažící posluchače zapalovat, kdežto Vocelův učenecký projev byl poněkud suchý.)

To nepochybně ovlivnilo i podobu přednášek. Kollár ty své charakterizuje hned v prvním proslovu (príloha 1): „Unsere Vorträge werden nicht so wohl ununterbrochene, streng an System und Methode sich bindende Vorlesungen, was schon der archäologische Stoff nicht erlaubt, der den Faden der Rede durch Anschauung oft unterbricht, sie werden vielmehr freie Unterredungen, archäologische Unterhaltungen, ja oft extemporirte Mittheilungen über meine Reisen und Erfahrungen, Beobachtungen und Entdeckungen sein. "Vocelovy naopak zřejmě odpovídaly v té době i později obvyklému zpo̊sobu, označovanému synonymem přednášky - „čtení“.

$\mathrm{Na}$ závěr se vrat'me obecně a jen zběžně k obecné situaci neklasické (pravěké a raně středověké) archeologie na evropských univerzitách. V době od 40. do 70. let 19. století, kdy v celé Evropě probíhala její konstituce jakožto vědního oboru, získala Praha její (pokud známo) druhou výslovně specifikovanou profesuru na světě (po Reuvensově 1818). Počítáme-li jen podmíněně Kollárovu katedru ve Vídni, jinak zaměřenou, stojí tak Vocelova profesura na počátku výše zmíněné první vlny, v níž následuje hned roku 1851 profesura Johna Marsdena v Cambridgi (1865 ji po něm převzal Churchill Babington; oba rovněž uveřejnili své vstupní přednášky - Marsden 1852, Babington

12 Poslední Kollárův úvodní proslov z 15. 10. 1851 je sice ve Vesně otištěn česky, ale $\mathrm{v}$ rukopise je dochována německá verze, takže zde možná šlo o dodatečný překlad do češtiny.
1865), 1854 Dublin a současně Kodaň, kde Jens Jakob Asmussen Worsaae začíná přednášet jako první severoevropský profesor tohoto oboru (ale jen s nepravidelným úvazkem); ve Švédsku je to podle očekávání univerzita v Lundu, kde na určitou tradici osobního archeologického zájmu některých dřívějších učitelů navazuje roku 1855 oficiálně Nils G. Bruzelius. Za evropským západem a severem zůstává pozadu nejen Německo, kde v této fázi nic podobného nevznikne, ale i Rakousko, kde po Praze nenásleduje Vídeň, ale Krakov (1863 resp. 1867 Józef Łepkowski, zaměřující se ale především na středověké umění). Tato vysokoškolská učební místa položila základ k vytváření personální základny nové vědy, z níž pocházela první, byt i zatím nečetná generace skutečných profesionálů, profilující se v období pozitivismu.

\section{Literatura}

Babington, C. 1865: An introductory lecture on Archaeology delivered before the University of Cambridge. Cambridge. Benda, K. 1980: Jan Erazim Vocel - zakladatel českého dějepisu umění. Umění 28, 1-21.

f. Z. 1850: České přednášky na Pražské universitě. Květy $16,15$.

Karásek, f. 1893: Jan Kollár ve Vídni 1849-1852. In: Pastrnek, F. (ed.), Jan Kollár (1793-1852). Vídeň, 62-77.

Kazbunda, K. 1965: Stolice dějin na pražské universitě 2. Praha.

Kollár, 7. 1832: Výklad čili Př́mětky a vysvětlivky ku Slávy dceře. Pešt'.

Kollár, F. 1849a: Rede gehalten 21. Mai 1849 bei Eröffnung der Vorlesungen über slawische Archäologie. (Rkp., Literární archiv Památníku národního písemnictví, Praha, fond J. Kollár.)

Kollár, F. 1849b: Řeč při druhém otevření archaeologických přednášek na c. k. universitě ve Vídni dne 5. listopadu 1849 od Jana Kollára. Národní noviny č. 266 (10. 11.), 1039.

Kollár, F. 1851: Přímluva při otevření archäologických přednášek 15. ř́jna 1851 ve Vídni. Vesna 1, č. 118 (25. 10.), 487-488.

Marsden, f. H. 1852: Two introductory lectures delivered in the University of Cambridge. Cambridge.

Otruba, M. /mo/1993b: Jan Kollár. In: Forst, V. (ed.), Lexikon české literatury 2/II. Praha, 793-803.

Petráñ, f. 1983: Nástin dějin filozofické fakulty Univerzity Karlovy. Praha.

Salač, V. 2006: Nástin dějin archeologie na univerzitách v českých zemích do druhé světové války. Studia mediaevalia Pragensia 7, 131-155.

Sklenář K. 1968: Archeologický sbor Národního muzea. In: Burian, M. - Špét, J. (red.), 150 let Národního muzea v Praze. Praha, 91-101.

Sklenář, K. 1971: Jan Erazim Vocel a počátky archeologické vědy v Čechách. Památky archeologické 62, 315-321.

Sklenář, K. 1980: Archeologická činnost Josefa Vojtěcha Hellicha v Národním muzeu (1842-1847). Sborník Národního muzea v Praze 34, A, č. 3-4, 109-235.

Sklenář, K. 1981a: Jan Erazim Vocel. Zakladatel české archeologie. Praha.

Sklenářr, K. 1981b: První profesura archeologie na Karlově univerzitě v Praze. Praehistorica VIII (Varia archaeologica 2), 13-17. 
Sklenár r. K. 1983a: Archaeology in Central Europe: The First 500 Years. Leicester - New York.

Sklenář, K. 1983b: Vývoj prehistorické vědy v Evropě. In: J. Bouzek - M. Buchvaldek - P. Kostomitsopoulos - K. Sklenář, Dějiny archeologie I. Praha, 7-169.

Sklenář, K. 2005: Biografický slovník českých, moravských a slezských archeologů a jejich spolupracovníků z př́íbuzných oborů. Praha.

Sklenáŕ, K. 2014: Pravěká a raně středověká archeologie v dějinách Národního muzea. (Fontes archaeologici Pragenses 40) Praha.

Sklenár K. 2020: Archeologie v Čechách v období romantismu (1802-1868). Od Josefa Dobrovského po Jana Erazima Vocela. Praha. (Fontes archaeologici Pragenses 47.)

Skutil, f. 1944-48: Jan Kollár a archeologické památky. Sborník Muzeálnej slovenskej spoločnosti 38-42, 69-111.
Skutil, f. 1947: Jak vypadaly Vocelovy přednášky z české archeologie roku 1851. Věda a život 13, 191.

- „- 1951: Počátky slovanské archeologie. Sto let od zahájení Kollárových přednášek o slovanské archeologii. Lidová demokracie 3, č. 243 (14. 10.).

Šimek, E. 1950: 100 let české archeologie na pražské universitě. $\mathrm{Z}$ dávných věků $2,169-171$.

Wocel, f. E. 1850a: Účel a význam archeologie české. Časopis Národního muzea /tehdy Časopis Českého museum/ 24, 115-126.

Wocel, J. E. 1850b: Česká archeologie křestáanského středověku. Časopis Národního muzea 24, 541-555. /Též sep., Praha 1850./

Wocel, f. E. 1852: Vyvinování křestanského umění a nejstarší počátky jeho, zvláště v Čechách. Časopis Národního muzea $24,1,37-71 ; 2,3-40$.

Zagiba, F. 1965: Die erste Lehrkanzel für slawische Archäologie an der Universität Wien errichtet 1849. Slavia antiqua $12,143-152$.

\section{Textové přílohy}

Texty jsou reprodukovány $\mathrm{v}$ původní podobě, pouze $\mathrm{v}$ českých jsou velká počáteční písmena u př́davných jmen odvozených od jmen místních jmen (Pražský apod.) změněna na malá a písmena pravopisu obvyklého před r. 1848 sjednocena na dnešní způsob: $\mathrm{g}$, př́p. $\mathrm{y}=\mathrm{j}, \mathrm{au}=\mathrm{ou}, \mathrm{w}=\mathrm{v}$; kolísání i-y (kromě vlastních jmen a cizích slov) sjednoceno na i. Výjimečně v prŕpadě potřeby upravena interpunkce. Kollárův rukopis (př́loha 1) v originále zkracuje und - u., oder - o.; tyto zkratky zde rozepsány.

Veškeré další zásahy editora jsou vymezeny lomítky resp. rovnými závorkami, at' už jde o /vsuvky a poznámky/, nebo naopak o místa jím vypuštěná, př́ípadně v rukopisech nečitelná či poškozená /.../; kulaté závorky ( ) jsou součástí původního textu.

\section{Př́loha 1.}

\section{Jan Kollár: První zahajovací přednáška slovanských starožitností na univerzitě ve Vídni v letním semestru 1849 \\ (přednesena 21.5. 1849)}

\section{Jan Kollár: The first opening lecture of Slavic antiquities at the University of Vienna in the summer semester of 1849} (delivered on 21 May 1849)

Kollár, F.: Rede gehalten am 21 Mai 1849 bei Eröffnung der Vorlesungen über slavische Archäologie / von Dor Foh. Kollár. (Rukopis: Knihovna Národního muzea, odd. rukopisü, sign. VI C 25.)

Meine Herren! Durch die Gnade Sr. k. k. Majestät als Professor zu dieser Lehrkanzel slavischer Alterthümer huldreichst ernannt, fühle ich beim Eintritte in dieses Amt, zwei Gesinnungen so stark und lebendig in meinem Herzen sich zu regen dass ich nicht umhin kann solche laut werden zu lassen, ehe ich das eigentliche Geschäft meines Berufes anfange. Diese Gesinnungen sind Dank und Bitte. Die erste Gesinnung, Gesinnung des innigsten Dankes fühle ich mich verpflichtet im Namen aller öster. Slaven, dem gütigen Monarchen und dem hohen Ministerium darzubringen, als den Gründern von vier slav. Lehrkanzeln dieser Stadt und diesen Universität, nämlich Lehrkanzel der čechischen und der polnischen Sprache, Lehrkanzel der slav. Sprache und Literatur überhaupt und endlich diese Lehrkanzel der slav. Archäologie und Mythologie. Dänken Völker ihrem Regenten für politische und materielle Wohlthaten, für Eisenbahnen und dem Schiffahrt, für gute Gesetze und Verfassung an, für Beförderung des Handels und der Industrie durch Fabriken und Manufakturen! so ist es wohl eine noch heiligere Pflicht auch für geistige Wohlthaten zu danken, als da sind gut eingerichtete Schulen und Bildungsanstalten, tüchtige Lehrer und Professoren, Bibliotheken, Sammlungen von Kunstschätzen und Alterthümern, Katheder für besondere Zweige und Fachen der Wissenschaften, damit diese desto gründlicher und vielseitiger erfasst und dargestellt werden. Und diese Wohlthat ist bei der neuen Gestaltung des öster. Gesamtstaates den 
slav. Stämmen schon in einem so reichen Maasse zu Theil geworden, wie vielleicht keinem! andern Volksstamme. Darum haben wir alle Ursache herzlich zu danken diesem unsern Wohltätern.

Der zweite Gefühl, dass ich heute und mit mir gewiss auch Sie alle meine Herren, im Busen und auf den Lippen tragen, ist eine Bitte: fromme, vertrauensvolle Bitte zu dem Weltenvater, dem Lenken der Schicksale aller Staaten und Völker, es möge nach seiner unendlichen Macht und Weisheit der geweihten Sache unseres Thrones den tapfern Waffen unseres Heeres bald einen entscheidenden ruhmvollen Sieg verleihen, dem unseligen Blutvergiessen ein Ende machen, das Getöse des Krieges in stille Ruhe und völkerbeglückende Frieden verwandeln, die Wühler und Aufrührer zur Ordnungsliebe bringen, die Herrschsüchtigen und die Unterdrücker Anderer zur Anerkennung der Billigkeit des Gesetzes der Gleichberechtigung aller Völkerstämme führen, welches Gefühl das grösste Geschenk des gegenwärtigen Zeitgeistes und die schönste Zierde der Menschheit ist. Nicht Feigheit oder ängstliche Todesfurcht, sondern die Ehre der Menschheit und der Wunsch nach dem wahren Glücke der Völker führt uns dazu, dass auch wir mit dem klassischen Dichter Virgil ausrufen: „Nulla salus bello, pacem te poscimus omnes“, dass auch wir dem ehrwürdigen Priester der Humanität Herder beistimmen: „Nur in dem Boden des Friedens gedeiht die zarte Blume der Humanität."

Wir fangen unser Werk unter den, wenigstens scheinbar, ungünstigsten Auspicien an, in einer Zeit, in der politische Stürme toben und die Gemüther, beherrscht von den Tagesereignissen, wenig Lust spüren von der fesselnden Gegenwart in die Vergangenheit zu blicken und mit ernsten Betrachtungen sich zu beschäftigen. Dennoch soll uns das nicht entmuthigen. Meister über die Zeit zu werden, uns in den flüchtigen Gegenwart nicht zu verlieren, uns mit den Tagesereignissen nicht $\mathrm{zu} / \ldots /$, sondern über sie erheben und in allen günstigen oder ungünstigen äusseren Welterscheinungen die innere Ruhe und Würde, das klare, wundervolle Selbstbewusstsein tu behalten. Zu dieser Erhebung und Gleichmüthigkeit des Geistes, zu dieser Seelenruhe führen aber eben nur die Musen. Hoffentlich wird auch bald die Zeit kommen, wo der Krieg dem Frieden, die Leidenschaften der Vernunft, doe Fausterstrengung der Geistesarbeit Platz machen wird, denn das ist ja die erhobene Bestimmung der Menschheit.

Was nun den Zweck unserer Zusammenkunft und den Gegenstand unseren Studien anbelangt, erlauben Sie mir, das ich Sie darüber von vorn hinein orientire und andeute, was sind Sie von mir zu erwarten haben und wie wir Beide vereinigt diesen Weg zu dem erhabenen Heiligthume der Alterthumswissenschaft schreiten wollen. Ich weiss Sie erwarten viel, vielleicht gar zu viel von mir, wäre ich mir im Stande dieser Erwartungen einiger massen zu entsprechen. Der Geist ist zwar willig doch der Leib manchmal schwach. Dreissig volle Jahre opferte ich einem, zwar wichtigen, aber sehr beschwerlichen Amte, in einer unfreundlichen Umgebung, die mir meine Gesundheit und die letzte Hälfte des männlichen Alters kostete. Lebensmuth und Lust zu Arbeit fühle ich zwar in mir noch minen, aber dennoch muss ich Sie bitten Geduld und Nachsicht mit meinem manchmal schon schädlichen Gesundheitzustand zu haben.

Unsere Vorträge werden nicht so wohl ununterbrochene, streng an System und Methode sich bindende Vorlesungen, was schon der archäologische Stoff nicht erlaubt, der den Faden der Rede durch Anschauung oft unterbricht, sie werden vielmehr freie Unterredungen, archäologische Unterhaltungen, ja oft extemporirte Mittheilungen über meine Reisen und Erfahrungen, Beobachtungen und Entdeckungen sein.

Lange dachte ich mich darüber nach, in welcher Sprache ich diese Vorträge halten sollte, ob slavisch oder deutsch. Meine Forschungen selbst fühlte, dachte, schrieb ich zwar čechisch-slavisch, doch weil die Kenntniss des čechischen Dialekte noch nicht allen Slaven eigen ist, wird vielleicht doch auch einige deutsche Zuhörer an unseren Stunden und Vorträgen Antheil nehmen dürfen, so gab ich dem Rathe umsichtiger Freunde nach und wählte zum Vortrag die deutsche Sprache. Nur bitte ich die germanischen Puristen sich an etwaigen Slavismen eines geborenen Slaven nicht zu stossen. Und am Ende wird hier keine Sprache zu kurz kommen, die deutsche wird das Vehikel und Mittel, die slavische der Gegenstand und Zweck, so dass wir beide brauchen und hören werden und zwar diese letzte beinahe in allen ihren Mundarten. Ich führ Sie in ein neues, unbekanntes Land, in eine alte, wunderbare, geheimnisvolle Welt. Der Schwierigkeiten dabei bin ich mir sehr wohl bewusst. Wir unternehmen einen Kampf gegen 18 Jahrhunderte, ja gegen 2000 Jahre, gegen ganz Europa, gegen die ganze gelehrte Welt. Es wird nicht an Zweiflern und Gegnern, nicht an Spöttern und Witzlingen fehlen, wenigstens Anfangs, weil viele das, was mit ihren vorgefassten Meinungen nicht übereinstimmt, gerne lächerlich oder zweifelhaft machen. Auch diess Alles soll uns nicht beirren. Unsere Sache ist zu ernsthaft, als dass wir leichtsinnige oder oberflächliche Angriffe beachten und beantworten wollten. Wir haben sprechende Beweise und Zeugen, darum werden wir selbst schweigen.

Unsere Alterthumskunde des slav./ischen/ Altitaliens macht ein Ganzes, Zusammenhängendes aus, von mir einzelne Wörten und Sachen oder abgerissene Stücke und Sätze hört, wird uns schwer oder gar nicht begreifen. Darum bitten wir, dass Niemand voreilig und einseitig urtheile, sondern billig und ruhig wo nicht 
das Ende doch wenigstens die Mitte abwärts. Dann werden wir ein feines, gegründetes Urtheil nicht nur gerne hören, sondern auch zum Besten der Wissenschaft benützen.

Wie in der ersten Hälfte meines Lebens die Poesie meine höchste Wonne, und liebste Beschäftigung war: so haben mich in der zweiten älteren Hälfte die Geschichte und die Alterthümer meiner Nation unwiderstehlich angezogen und am schönsten beglückt. Dort hat in meinem Geiste die Phantasie und das Gefühl vorhergeherrscht; hier mehr der Verstand, das Urtheil und die Kritik. Dort war mir das Schaffen und Produziren lieber, hier mehr der Genuss, das Suchen der Trostes für eine traurige Gegenwart und die Hoffnung für eine bessere Zukunft. Die Seligkeit des Schaffens geniesst ja auch derjenige. der das Tode auferweckt, um das Vergangene und Verschwundene noch einmal zurück zum Dasein ruft. Darum machte ich oft und gerne aus dem Lande, wo ich wohnte, Reisen in andere entferntere Länder und begab mich aus der Jetztzeit in verschwundene Jahrhunderte, um mir auf diese Art gleichsam den Geiz und Misgenuss des Schicksales gegen unsere Nation zu ersetzen. Die Resultate davon, wie ich Anfangs selbst nicht ahnete, werde ich auf ihnen, wenigstens zum Theil mittheilen, was mein ist, soll auch Ihre werden. Wie der Naturforscher von den versteinerten, aus den Tiefen der Erde ausgegrabenen Blättern und Zweigen, Gebeinen und Zähnen auf eine vergangene, längst ausgestorbene Welt schliesst, aus ihnen ganze Blumen und Bäume, Skelette und Thiere zusammenlegt, ihre Gattung und Lebensart bestimmt, ihren Zusammenhang mit der jetzigen Schöpfung nachweist: so findet auch der slav. Archäolog in Italien überall Ruinen, Bruchstücke, Elemente und andere Uiberreste einer untergegangenen Sprache und eines verschütteten Lebens, die er erst sammeln, in ein Ganzes vereinigen und dann ihre Identität, theils mit den bereits verschwundenen, theils mit den neuen slav. Leben zu zeigen hat. Denn so wie ein grosser Theil Deutschlands eine slav. Wineta ist, verschlungen und begraben durch die Wellen des german. Balts: so ist ganz Italien ein slav. Herculanum und Pompeji, verschüttet durch die Lava und Asche der Graecomanie. Dieses auszugraben, zu enthüllen, zu erklären oder wenigstens die Aufmerksamkeit des Slaventhums dahin zu lenken ist die Aufgabe eines slav. Alterthumsforschers, ist auch die Absicht dieser Vorlesungen. Darum werden wir bei diesem Geschäfte mehr den synthetischen als den analytischen Weg befolgen, in dem ohne die Kenntniss einzelnen und wirklichen Sachen hier alles historische Spekulieren, alles theoret. Vernünfteln und Etymologisiren nichts nutzl. Zum Glück aber haben diese einzelnen, hie und her zerworfenen, dem Anscheine nach unbedeutenden Bruchstücke die vortreffliche Eigenschaft und den hohen Werth, dass sie fähig sind sich gegenseitig zu ergänzen und uns so zu der Vorstellung über das Ganze zu führen. Nichts ist leichter, aber auch nichts verführerischer und trügerischer als das Idealisieren und eigenmächtige a priori Grübeln oder gar eine romantische Schwärmerei in antiquarischen und historischen Sachen ohne einem materiellen Boden und wirklichen Grund. Darum werden wir, wo es möglich ist, überall beide die Data und die Urtheile der Augenzeugen und der glaubwürdigen Klassiker einführen und hören und zwar in dem Originaltext, damit sich so das alte Italien selbst mit eigenen Farben vor unseren Augen male und darstelle. Ich fühle die Grösse, ja ich möchte beinahe sagen, die Kühnheit meines die Kräfte eines Individuums übesteigenden Unternehmens, ich weiss wohl, welch eine sauere und doch oft undankbare und vergebliche Mühe es sei, tausendjährige Irrthümer anzutasten, eingewurzelte Vorurtheile zu widerlegen, alten Sachen eine Neuheit, den neuen eine Glaubwürdigkeit, den dunkeln eine Klarheit, den verblichenen einen Glanz, den langweiligen ein Reitz, den zweifelhaften eine Gewissheit, geschwiege denn, den Todten ein Leben und den begrabenen eine Aufstellung geben zu wollen: demungeachtet muss aber doch einmal der Anfang gemacht werden, denn andere das schwache Angefangene berichtigen und vollenden können. Es ist möglich ja wahrscheinlich dass auch von uns manches etruskische, umbrische und oskische Wort unrichtig gelesen und übersetzt wird und der Berichtigung bedarf; doch leicht wird es sein dem einmal Entdeckten und Gefundenen zuzugeben und und auf dem angebahnten Wege fortzuschreiten.

So was ist nicht und kann nicht das Werk eines Menschen, auch nicht einen oder zweier Weisen, nicht eines oder zwei Jahren sein, sondern ganzen slav. Vereine, Länder, Regierungen, vielleicht ein Jahrhundert hindurch, bis die Sache zu dem erwünschten Grade die Allseitigkeit und Klarheit gebracht wird. Ich hielt mich in Italien nur einige Monate auf, reiste dahin zweimal auf eigene Kosten, von Niemandem unterstützt, von keinem Mäcen, von keiner gelehrten Gesellschaft anempfohlen wie andere, in diesem Hinsicht glücklichere Reisende und Alterthumsforscher. Selbst der Bearbeitung der dort gesammelten Materialien konnte ich, nach der Rückkehr in die Heimath, nicht die ganze Zeit, wie viele englische, französische oder deutsche Gelehrte, sondern nur die, von Amtsgeschäften übriggebliebenen Stunden widmen. Nachdem ich aber zu der Uiberzeugung gekommen, dass die Zahl meiner noch übrigen Lebensjahre nicht hinreichen würde zum völligen Erschöpfen dieser ganzen tiefen und reichen Quelle von AltItalien, so eile ich gerne am Abende meines Lebens ihnen noch die mühsam gesammelten Entdeckungen und Bruchstücke mitzutheilen, damit sie für die Nachkommenschaft nicht verloren gehen. Diess wollte ich voraus schicken, nicht um mich zu entschuldigen, 
sondern nur Ihnen einige vielleicht nicht ganz erschöpfte und vollendete Seiten meiner slav. ital. Forschungen begreiflich zu machen.

Obwohl mir schon in meiner Jugend viele lateinische Wörter wie slavisch in den Ohren klangen, und nicht einmal wunderte ich mich darüber, woher es komme, dass in unseren Schulen geborene Slaven so gerne und so leicht das Latein lernen, indem das den Schülern anderer Nationen um vieles schwerer fällt? Nichts destoweniger bin auch ich in dem allgemein herrschenden europäischen Vorurtheil aufgewachsen, dass das Latein eine Originalsprache sei. Meine erste Reise in Ober-Italien im J. 1841 erschütterte mich mit grossen Misstrauen zu den gewöhnlichen Ansichten europäischer Gelehrten und Sprachforscher. Aber erst die zweite im J. 1844 unternommene Reise ins Mittel- und Unter-Italien nahm mir den Schleier vom Gesicht. Als ich da in Rom und dessen Umgebung theils von meinen Ciceronen gehört, theils mit eigenen Augen gelesen die Namen der Flüsse Tepula oder Tepla, Juturna (Jitrna), Egerin (Agra), Tiber (Dobr); die Namen der Berge Tarpejus, Saturnius, Palatinus, Aventinus, Carmelus, die Namen Coliseum, Sublicius pons, Subura und dergl., erst da bei dieser Autopsie und Handgreiflichkeit fiel mir die Feder eines gewöhnlichen Reisebeschreibers aus der Hand, in meinem Geiste geschah eine völlige Umwälzung, ich versank in stumme Betrachtung und fing an mich meiner bisherigen Sprödigkeit und Hartglaubigkeit selbst zu schämen. Nicht selten war ich gegen meinen eigenen Sententien argwöhnisch und sprach zu mir selbst „Es waren ja hier vor dir so viele gelehrte und wahrsinnige Slavisten, die hätten das gewiss wahrgenommen, wenn hier etwas Slavisches wäre“ - aber als ich dann Ausflüge machte in das benachbarte Latium, Sabinie und Volskenland, hörte die Namen des Flusses Crabra oder Chrabra, der Stadt Lavinia oder Slavinia, Aricia oder Horica, Pometia, Pomtina oder Pomatina, als ich nach Herculanum, Pompeji, Paestum und dann wieder nach Etrurien kam - hörte jeder Zweifel auf und ich stand in der Mitte Italiens wie in der Mitte Slaviens umlauft von allen Seiten von slavischen Tönen und Lauten in den Namen der Berge, Thäler, Flüsse, Seen, Dörfer und Städte.

Ich weiss es im voraus, dass es auch jetzt noch unter den Gelehrten manchen unglaubigen Thomas geben werde, viele werden hier nichts anders sehen lassen, als jene allgemeine Verwandschaft der indoeuropäischen Sprache und keine besondere slav. Stamm- und Dialektverwandschaft. Ich, jeden geistigen Zwang hassend, lasse recht gerne einen jeden bei seiner individuellen Uiberzeugung, und will nie wahre und vernünftige Gründe, falls sie irgendwo vorgetragen werden, unbeachtet lassen. Möglichst grösste Berichtigung und Vervollkommnung sowohl meinen eigenen Kenntnisse als auch der Geschichte unserer Nation ist mein einziger höchster Zweck. Auch diess ist mir nach eigener Erfahrung kein Geheimniss, dass die Italiener selbst, wie sie jetzt sind, unsere Forschungen und Resultate nicht werden begreifen wollen, ja sich vielleicht ihrer slavischen Ursprungs schämen, und den Urheber dieser neuen Entdeckung und Ansicht für einen Mann hatten der etwa aus dem Monde gekommen ist, der nie etwas von Avellini, Gosi, Geasini, Anghirami, Lanzi, Micali, Prelli gehört, desto weniger noch das mare Historiarum von Giovanno Colonna gelesen hat, die doch alle die ältesten Bewohner Italiens samt ihren Sprachen nicht von den sklavischen, in der Geschichte verachteten Slaven, sondern von den stolzen, kriegerischen, hochgeehrten und vergötterten Hellenen ableiten. Die Geschichtsschreiber sind oft so wie die gemeinen Menschen, die verachten oder gar misshandeln den, der nicht herrscht, nicht glänzt, nicht im Glücke ist. Zum Troste solcher von einem falschen Scham befangenen Herrn bemerken wir nur dass jene Griechen schon waren und nicht mehr sind, die Slaven aber waren und sind noch und werden, wie Gott will, auch noch da sein; dass Zeiten kommen werden und sind schon im Antritt wo es keine Schande sein und wird den Slaven anzugehören, es sei in der Vergangenheit oder in der Gegenwart. Europa! dass da es doch einmal sagen, öffne und wende doch schon einmal deine Augen auf das Slaventhum, glaube, dass deine Geschichte so lange nicht vollständig und wahr sein wird, bis du diess nicht thun weiss.

Wer die Resultate dieser unseren Alterthumsforschungen begreifen und verfolgen will, der muss drei Vorurtheile von sich entfernen, das 1te ist, als ob die Römer alles nur von den Griechen genommen hätten, das 2te als ob die Slaven erst seit dem 6. oder 5.ten Jahrh. in Europa wären, das 3te endlich, als ob die griechischen, lateinischen und germanischen Etymologen und Alterthumsforscher allein die Wahrheit an ihrer Seite hätten. -

Ich fühle es, dass für ähnliche Arbeiten und Ansichten noch ein grosses Theil des slavischen Publikums nicht reif und vorbereitet sei; aber wird denn unsere Nation immer und ewig bei dem Lesen der ABCbücher, der Kalender und der Zeitungen bleiben?

Meine slavisch italischen Entdeckungen und Alterthümer haben allerdings auch etwas tragisches, niederschlagendes, man wir sagen, dass diese Helenisirung der Slaven in Italien eben so wenig zur Ehre und Freude unsern Nation gemacht, wie ihre Entnationalisirung und Metamorphose in andern Ländern. Dennoch hat dieses Werk nicht bloss eine unangenehme, sondern auch eine angenehme Seite für die Slaven. Seitdem als ich mich in Italien umsah, öffnete sich meinem harrenden Blicke noch ein neues, und zwar das älteste Theil der Sprache, der Mythologie, der Gesetze, der Künste, und des ganzen Lebens. Erst hier werden wir uns selbst 
recht kennen lernen und werden nicht mehr bloss auf die einseitigen Nachrichten der befangenen Griechen und magern Chronisten über unsere Vorfahren beschränkt. Dadurch erweitert sich bedeutend der Gesichtskreis unseres Nationallebens, unserer alten Geographie und unsere Geschichte gewinnt einen Zeitraum von mehreren Jahrhunderten. Unser treffliche Šafařik war der Erste, der in seinen slavischen Starožitnosti den Weg und der Art zeigte, wie eine, unsere Nation würdige Geschichte geschrieben werden soll; was er gethan in der einen Helfte unserer Nation und Geschichte, nämlich in der christlichen Epoche, das bleibt noch übrig zu thun in seinen zweiten Helfte, nämlich in den vorchristlichen, heidnischen Epoche. Šafařik hatte freilich die lichtvolle Seite, ausgiebige un sicherere Quellen, einem reicheren, edleren und ausgebildeteren Stoff für seine historische Schöpfungen vor sich, nichts destoweniger aber lässt sich auch aus abgerissenen, fragmentarischen, dürftigen und den Keimern gleich zerstreuten, aber fleissig gesammelten und sinnig geordneten Notizen zwar nicht ein glanzvolles Raphaelsches Bild, doch wenigstens eine interessante Mosaik schaffen, in der wir, wie in einem Spiegel die Vergangenheit erblicken. Die Wissenschaft und Kunst unserer Zeit steigt herab auch in dunkle Gräber, gräbt ihre Särge und Aschenkrüge aus und macht Schlüsse aus den Denkmälern des Todes auf das Leben der Völker. Erst dann werden wir eine ganze, vollständige und vollkommene Geschichte der Slaven besitzen, wenn wir auf diese Weise alle slavische Länder und Zeiten erschöpfen, ausbeuten, erforschen und zu einem Ganzen vereinigen werden.

Ja selbst die lateinische Literatur und ihre Klassiker Cicero, Virgil, Horaz, Livius und andere, wenn man sie von diesem Standpunkt betrachtet, zeigen sich uns in einem anderen Lichte, sie bekommen für die Slaven nicht nur mehr Deutlichkeit und Verständlichkeit, sondern auch einen neuen Reitz, eine höhere Bedeutung; denn sie sind unsere und zwar in einem weit engern, wahreren und näheren Sinne unsere, als der übrigen Nationen. Keine National-Zwischenband trennt uns von ihnen, sie sind nicht bloss Blut von unserem Blute und Leib von unserem Leibe, sondern auch Geist von unserem Geiste. Wenigstens mir hat kein Fund und keine Entdeckung in meinem Leben eine grössere Freude verursacht als die Erscheinung des Slaventhums in Alt-Italien. Hier haben die Slaven, obgleich mit den Griechen vereinigt, doch in gewissem Sinne auch selbständig ein grosses Lehen der Welt gezeigt und übergeben, und vortreffliche Geschenke der Menschheit gebracht: die in anderen Ländern entnationalisirten Slaven dagegen nichts, hier gingen sie verloren, sowohl für das Slaventhum, als auch für die Menschheit. Diese lebendige Verwandschaft mit Italien ist, so wie hinsichtlich der Zeit näher und gegenwärtiger, hinsichtlich des Raumes nachbarlicher, so auch hinsichtlich der Folgen viel wichtiger und nützlicher für unsere Tradition und deren literarische Zukunft, als jene kalte und todte Verwandschaft mit dem indischen, chronologisch und geographisch von uns so sehr entfernten sanscrit.

Es ist auffallend, dass von den unzähligen Schulgelehrten und Historikern Europas, so viele Jahrhunderte hindurch, doch keiner auf der Gedanken kam Italien und Rom mit Slaven und der slavischen Sprache ernstlich, allseitig und kunstgemäss zu vergleichen. Denn was bis jetzt von den Unsrigen oder den Fremden in dieser Hinsicht geschah, sind mehr gelehrte Spielereien und Fragmente als wissenschaftliche Erzeugnisse. Ich übergebe die Erklärungen einzelner Wörter und Namen durch dalmatinische Slavisten in den vorigen Jahrhunderten und erwähne, dass in neuerer Zeit der Serbe Paul Solanič, ein Büchlein unter dem Titel: Rimljain Slawenstwowawsi, Ofen 1818 herausgab, da sich bloss auf eine mehr oder weniger gelungene Vergleichung lateinischer Wörter mit den slavischen beschränkte. In Petersburg kam im J. 1846 heraus „Caromntje, ili swjaščenyj jazyk magow, wolchwow i žrecow" von Platon Lukašewsky, dem nichts fehlt, als die Kritik. Ein franz. Werk: Observation sur la ressemblance frappante que l'on decouvre entre la langue des Russes et cette des Romains, Mailand 1817 ist uns noch nicht zu Gesichte gekommen. Aehnliche Werke einiger Deutschen z. B. der germanische Ursprung der lateinischen Sprache und des römischen Volkes von E. Jaeckel, Berlin 1830, oder: Zwei deutschen Inschriften älter als 600 Jahre vor Christus aus dem Lateinischen übersetzt ins Neudeutsche durch K. A. Fr. von Schmitz-Auerbach, Heidelberg 1848, verdienen kaum erwähnt zu werden und haben für die Sache der Wissenschaft ohngefähr einen solchen Werth, wie die untergeschobenen Schriften und Machwerke unter dem Namen Messala, Fenestella, Modestus, Annius von Viterbo und andere über den Ursprung der Römer. Nüchterner und vernunftiger benehmen sich in dieser Angelehengeit Niebuhr, Ottfried Müller, Lepsius, Goethe und A., die alle bald überhaupt ein fremdes, bald insbesondere ein nordisches Element in Latein fanden erkannten, aber dieses Element anzugeben und zu nennen hat sich keiner von ihnen getreut, sie gingen um dasselbe herum, wie dort die Athenienser um den Altar des unbekannten Gottes. Einige suchten dieses Element, sogar in der entlegensten Entfernung:in Egypten, in Armenica, in Palästina. Niemand sah die Länder und Völkerstämme, die gleichsam vor der Nase standen, in der nächsten unmittelbaren Nachbarschaft von Italien, nämlich die Veneter, Illyrier, Noriker. Man sah den Wald vor Bäumen nicht. Von den Bergen und Thälern Ragusas in Dalmatien kann man mit blossem Auge beim heiteren Wetter über das adriatische Meer Italien, dessen Ufer und Apenninen sehen. Flösse und kleine Schiffe der dortigen Schiffer 
kamen beim günstigen Winde in einigen Stunden zu den Frentanen oder Brodanen und nach Apulien oder Opolje. Bei dieser Nachbarschaft, ja unmittelbarer Berührung, was war natürlicher als slavische Colonien in Italien schon in den ältesten Zeiten?

Nach der Versicherung des bekannten Gelehrten Pogodin soll Göthe, als er zu Palermo in Sicilien war, zu welcheren dort eben auch anwesenden slav. russischen Reisenden die prophetischen Worte gesagt haben: „Italien ist für kein Volk so wichtig und merkwürdig, als für die Slaven.“ Ein Beweis, dass Göthe nicht bloss ein grosser Dichter und Naturforscher war, sondern dass er auch in der Geschichte und Archäologie vortreffliche Kenntnisse, ein eigenes richtiges Urtheil oder vielmehr jene seltene poetische, zwar noch dunkle aber untrugliche Ahnung und Sehengabe im hohen Grade hatte. Zu der Ausserung gab das Gespräch über die alte Slaven-Vorstadt und die slavische Gasse in Palermo die Verlassung.

Zwischen den oskischen oder umbrischen Dialekt in Italien und zwischen den übrigen damaligen slavischen Dialekten war gewiss kein grösseres Unterschied als z. B. zwischen dem Drewanschen oder Polabischen und dem čechischen oder zwischen dem polnischen und russischen. Selbst das Latein, je älter und vom griechischen Einfluss entfernter, desto ist es dem slavischen näher und verwandter wie es die Schriften Catos, Ennius, Plautus bezeugen. Dass sich in folgenden Zeiten die italischen Mundarten in einigen Formen von slavischen entfernten: Ursachen davon sind theils die dass sie auf einem Insel lebten isolirt vom Meer umgeben, sich selbst überlassen, indem sie nördlich von dem Slaventhume durch die Alpen, Celten und Germanen abgeschnitten, südlich aber unter dem Einflusse und dem Druck des zudringlichen Hellenismus und der Gräkomanie standen, die von allen Seiten eine Gewalt auf sie ausübten. Würde Jemand einwanden, dass z. B. das Wort panis nicht slavisch sei und in keiner der jetzigen slavischen Mundarten vorkomme, dem könnte man antworten, dass auf diese Art auch die Wörter chleb und kruch nicht slavisch wären, indem jenes auch bei der einen Helfte der Slaven und dieses bei der anderen unbekannt und ungebrauchlich ist, und dennoch finden wir wieder diese beiden Wörter in den altitalischen Mundarten, chleb in umbrischen, kruch im oskischen Dialekt auf einem frentonschen Inschrift! - Wie viele hundert Wörter haben die den Čechem so nahe stehenden Polen, welche im Čechischen gar nicht zu finden sind, z. B. Krnombrny, buta, księzyc und s. w. Wié viele Ausdrücke haben die Illyrier die man im Polnischen oder Russischen umsonst sucht, und wer wird ihnen dennoch nicht nur ihre Slavinität, sondern auch einen ächt slavischen Ursprung und slavische Wurzel streitig machen? Beinahe eine 3000jährige Isolirung und Unwechselseitigkeit liegt, gleich einer Kluft zwischen uns, jede Parthie betrat einen anderen Weg in ihrer Entwicklung und Bildung, die Slavo-Italen gingen den südlichen Weg in Gesellschaft dr Griechen, wir den nordischen in Gesellschaft der Germanen. In solchen Verhältnissen musste die Sprache und der Charakter Abweichungen und Verwandlungen erleiden. Die lateinische Sprache ist ursprünglich eine von den altslavischen Mundarten, nur etwas durch griechische Influenz modificirt, ihr ganzer Bau und Fluss ist slavisch, dieselbe Gramatik und Syntax, dasselbe Missbrauchen der Artikel, dieselbe Deklination und Conjugation, derselbe numerus oratorius, dieselbe Prosodie. Hieraus lässt sich die grosse vererbte Liebe der Slaven zum Latein erklären, indem dasselbe bei manchen z. B. Chorvaten, Slavonen, Slovaken, Polen und anderen gleichsam eine zweite Muttersprache ist. Keine europäische Nation lernt die Lateinische so leicht, ich möchte beinahe sagen, so leidenschaftlich, keine hat sich mit ihr so lange und so viele Jahrhunderte hindurch beschäftigt, keine hat sich gegen die Entfernung aus den Schulen und dem Leben so gesträubt, als die Stämme unserer Nationen. Im Mittelalter hiess Krakau in der ganzen gelehrten Welt kleine Rom, parva Roma, wegen des Eifers und der gelungenen Schriften in dieser Sprache. Den Polen Sarbiewsky setzt selbst ein Hugo Grotius dem Horaz zur Seite, ja oft über diesem, Johann Skorsky dichtete ein lateinisches Epos Lechiada, Janus Pannonius, Venantius oder Wranič der Cicero am tridentinischen Concil, Lobkowic, kropač, Balbin, Belius, Harulik, Konarsky und hundert andere Latino-Slaven sind Schriftsteller, wie sie die anderen Nationen wegen des ganz heterogenen Baues und Flusses ihrer Idiome nicht 6 haben. Vom Amos Comenstus /!/ weiss man nicht, ob man mehr sein klassisches Latein oder sein klassisches Čechisch bewundern soll. In unseren Jugendjahren war es nichts Neues Slovaken hiter dem Pfluge oder bei einer anderen Arbeit lateinisch discuriren zu hören.

Ein anderes Schicksal hate die etruskische Mundart, diese nahm einen anderen Gang, diese von zwei oder auch mehreren Nebenbuhlerinnen, nämlich der griechischen, der phönizischen, dann der iberischen und celtischen umringt, stand isolirt da, und weil sie um sich herum keinen Widerhall und keine Verwandschaft gefunden, verwelkte sie auch in der Nachbarschaft der hellenisierenden Römer und sank hin frühzeitig.

Beim Schlusse dieser meinen Rede erneuert sich meinem Gedächtnisse das Bild der herrlichen, glücklichen Tage, die ich in Italien verlebte und liebevolle Schatten umflattern mich. Für mich war das Reisen stets ein wesentliches Bedürfniss, es hatte für mich nicht bloss den gewöhnlichen Reitz der Neuheit und Mannigfaltigkeit, sondern auch einen höheren Sinn und inneren Werth. Die beste Begeisterung für Wissenschaft und Kunst ist die welche die Gegenwart und die Anschaulichkeit, den Umgang und den gegenseitigen Gedanken- 
austausch mit kenntnissreichen, im ihren Fache erfahrenen, mit uns gleichgesinnten Personen in uns weckt, die unmittelbare Erscheinung und Einwirkung der Musen auf unsere Seele, welche bei mir immer und überall das Beste was ich je war und dachte, hervorgebracht hat.

Folgen Sie mir, meine Herren! so werden Sie wenigstens im Geiste eine der angenehmsten Reisen von der Welt mit mir machen, eine Reise durch AltItalien angeweht überall von ehrwürdigen Urlauten unserer Muttersprache bewillkommt von der ältesten Göttern unserer Vorfahren, verweilend bei ihren Volksspielern, Gräbern; sie erblicken die ältesten Schiftzüge und Alphabete, in welche unsere Sprache wie in ein reiches orientalisches Kleid gekleidet wurde. Kurz AltItalien wie es vor der Ankunft de Griechen und Aeneas war, sammt Sicilien und allen den umliegenden Inseln und Ländern Helvetien, Rhätien, Noricum Illyricum, Dalmatien; in wiefern diese Ländern einen Einfluss auf AltItalien hatten werde ich nach Möglichkeit Ihnen darzustellen denn eine ziemlich reiche Sammlung von etruskischen, umbrischen, oskischen und altlateinischen Inschriften und literarischen Fragmenten wo sie 6v sehen werden, wie sich schon in dem etruskischen Dialekt der čechische, in dem umbrischen der polnische, in dem oskischen der illyrische, serbische, in dem altlateinischen der russische Dialekt abgespiegelt und sein Analogon findet. Vereinigen sie mit meinen Anfängen, Winkem und Andeutungen auch ihre eigenen ausführlichen Studien über die AltItalien und Sie werden auch mit einem süssen Gefühle bei der Beschäftigung mit einem so herrlichen Lande belohnt werden und dem alten Plinius mit ganzer Seele beistimmen wenn er sagte: Italia omnium terrarum alumna et parens, numine Deorum electa, que coelum ipsum clarius faceret, sparsa congregaret imperia /.../ Italia rectrix parensque mundi altera!

\section{Příloha 2. \\ Jan Kollár: Druhá zahajovací přednáška slovanských starožitností na univerzitě ve Vídni v zimním semestru 1849-50 \\ (předneseno 5.11.1849)}

\section{Appendix 2. \\ Jan Kollár: The second opening lecture of Slavic antiquities at the University of Vienna in the summer semester of 1849-50}

(delivered on 5 November 1849)

Řeč při druhém otevření archäologických prèednášek na c. k. universitè ve Vídni dne 5tého listopadu 1849 od Jana Kollára. (Rukopis: Literární archiv Památníku národního písemnictví, Praha, fond Jan Kollár.) ${ }^{13}$

\section{Milí Pánové!}

Vítám a pozdravuji Vás $\mathrm{v}$ tomto nově otevřeném studijním roce s novou radostí a s novými nádějemi, a to sice $\mathrm{v}$ naší milé národní slavočeské řeči, s radostí a díkčiněním $\mathrm{k}$ Bohu, onomu prameni života a umění, že nás živé a zdravé zachovati ráčil a spolu opět sejíti se nám popřál: ant mezi tím tak mnozí z našich známých a prátelů, zprava i z leva, jedni v bitvách, jiní v choleře zmizeli a se sladkým životem, oným krásným a libým zvykem bytí a působení, loučiti se museli. - Ale i s novými nádějemi nastupujeme do tohoto nového školského roku, s oněmi totiž, že bohdá již více nebudeme společně lkáti a úpěti a přišeptávati sobě to smutné př́sloví: „Inter arma silent Musae“, aneb „kde zbroj řinčí, Muzy mlči“; ale raději ze dne na den přivolávati sobě to potěšení: „Post trucem Martem regnet jam alma Minerva" aneb „po hrozných válkách blažená již Mudřena vládne“. -

Pozdravuji ale a vítám Vás národním naším jazykem, a to z mnohých příčin a ohledův. Předně a nadevšecko proto, že mne $\mathrm{k}$ tomu vlastní srdce mé a vroucí láska $\mathrm{k}$ milému našemu národu a jazyku pobízí a zavazuje. Pak zkušenost minulého léta mne poučila, že téměř všickni posluchači těchto starožitností Slávové byli, obzvláště k nářečí československému přináležející, pročež i vyvolil jsem k našim přednáškám toto československé nářečí, jako jedno z nejznámějších, nejrozšířenějších v našem mocnařství a snad i bez snadu vědecky nejvzdělanějších. Chcit zajisté, aby Slovanstvo vůbec aspoň jednu katedru a profesuru čistoslavjanskou mělo, kdeby i předmět, i jazyk, i věc i řeč slavonárodní byly, aby na této universitě a v tomto hlavním sídelním městě aspoň jeden repraesentatnt slavského živlu byl. To činím i proto, aby jsme tím ukázali, že my ten znamenitý dar který Jeho

13 Zde uložen jednak čistopis, použitý v této př́loze, jednak koncept odchylný v řadě pravopisných či jazykových detailů (zejména uživá německého tvaru Archäologie); Text je rovněž publikován v Národních novinách 2, č. 266 (10. 11. 1849), 1039, ale je zde místy zkrácen a navíc obsahuje celou řadu chybných čtení, někdy i zkreslujících smysl textu (staročeský místo slavočeský, líný místo libý, Řeků místo věků atd.), takže tuto publikaci nelze použít. 
císařské Veličenstvo všem věrným svým národům v rakouském mocnařství v státní soustavě dáti ráčilo, dar totiž a základ rovnoprávnosti, též živě cítíme, jej ochotně a vděčně přijímáme a i touto cestou, cestou učilišt', do života uvesti se snažíme, abychom i zde za jinými zpátkem nezůstali a od jiných převýšiti se nedali. Konečně děje se to i na výslovné pobídnutí a návěstí samého vysoce ctěného našeho ministra kultu a vyučování, jenž se ve známém svém posledním českém spisu „Úvahy o nynějších poměrech, hledíc zvláště k Čechám“, na str. 45 mezi jiným takto o této věci vyjádřil: „Zdá se nám, žeby se žádný předmět nehodil tak dobře, aby se o něm četlo v některém nářečí slavjanském, jako Archaeologie a starožitnosti slavjanské, kteráž věda ústavičně bude požadovati důkladů z etymologie slavjanské, jichž nikdo nedovede posouditi, a ani jim dokonale neporozumí, kdo se pilněji poněkud nezanášel studiemi jazyka slavjanského. Takovému ale nebude za těžko, aby poslouchal přednášku, nech se drží v jakémkoli nářečí slavjanském, a zvláště by byla každému Slovanu, přebývajícímu ve Vídni, jenž se obírá studiemi v dějinách a jazyku národu svého, ještě velevítaná př́ležitost, cvičiti se v nářečí příbuzném k materskému jeho jazyku, kterou by našel ve čteních archaeologických." - S tímto soudem slavného muže a vlastence i my se cele snášíme: a že jsme čtení tato minulého léta cizím jazykem otevřeli, to povážíme jediné co prozatímní výjimku místními okolnostmi a zvláštními ohledy nám naloženou. - Jestli by pak i někteří Němci neb jiných národů posluchači k těmto přednáškám se přidružili, vítáni nám, budou; slušná však věc jest, aby jako my se jiným jazykům, tak i jiní našemu jazyku se učili. Těžší však a důležitější místa v naší Archaeologii budou, jak posaváde, tak i budoucně, do více řečí, zvláště do německé a latinské překládána dílem pro všestrannější a zřetelnější objasnění, dílem pro snadnější pochopení věcí. Kdyby však snad některým v slavočeském nářečí zde přednešeným věcem nerozuměl aneb nedorozuměl, tomu svobodno bude ptáti se bud'v jiném slavjanském nářečí, bud'v německém a latinském jazyku. Ti Slavjané, bratři Poláci, Rusini, Srbové, Illirové, Slovenci, kteří ve slavočeském nářečí ještě jen počátečníci a nováčkové jsou, at' jen trochu trpělivosti mají: po několika týdnech a dnech jistě že jim všecko bude snadné a jasné.

I vracujemet' se tedy opět zpátkem k naší starovědě čili k Archaeologii a sice obzvláště k vědě slavo-italských starožitností. Co do názvosloví následovati budeme toto: Starověda - Archaeologia, něm. Alterthumswissenschaft, t. j. věda starého času a jeho obsahu vůbec, v přísný vědecký soustav uvedená, zde theorie i praxis, čas i věci v něm, forma i látka, literní i umělecké plody, duchovní i tělesný život, k. p. řeč, báje, pověsti, bohosloví, svátky, oběti, obřady, pak hmotné pozůstatky, rumy, zbořeniny, zdi, hroby, nápisy, obrazy, sochy, řezby, litiny a t. d. Starožitnost, starobylost starodávnost, starověkost, dřevnost, vetchost - pouhý starý čas a předešlá století, novějším věkům naproti postavená, dlouhé trvání něčeho, staří národové a jejich původ, bydla, děje; ponětí víc odtažené, než srostité a skutečné. - Stařina, množ. počet stařiny - staré věci vůbec, byt' samy v sobě i chatrnou cenu měly a jen stář́m a časem památny byly, opak noviny. - Starotina, množ. počet starotiny - staré, vzácné, znamenité a drahocenné věci, poklady a klenoty, zvláště umělecká díla, lat. antiquitates, něm. die Alterthümer, die Antiken, ve vznešenějším smyslu; opak novotiny; utvořeno dle obdoby prvotiny, drahotiny a t. d. - Starovědec - Archaeolog; starovědecký - archaeologisch. - Starotinoskuma - die Alterthumskunde, částka starovědy, zpytování a shomažd'ování jistého druhu starotin bez vědeckého pořádku; Starotinoskumec - zpytatel starotin, Alterthumsforscher. - Stařinář - Antiquar vůbec, staré chatrné věci sbírající a prodávající; starotinář, starotiník - Antiquar ve zvláštnějším smyslu, staré vzácné věci, knihy a umělecká díla shromažd'ující a prodávající, něm. der Alterthümler, Antiken-Sammler, Alterthumshändler. - Starotinárna, starotinec - sbírka, síň starotin, der Antiken-Cabinet. -

Tato starověda jest u nás nová, jest př́ijemná, jest odplátná ale při tom i pilnost a pořádek vyhledávající věda.

Nová věda jest naše starověda čili nauka slavjanské Archaeologie. Nemluvím nyní o klasické Archaeologii Řeků a Římanů, Indů, Egyptčanů, Peršanů, nýbrž toliko o novějších europejských národů, k nimž Slávové, co nejstarší a největší rodina, přináležejí. Jak zahanbeni a zarmouceni stojíme sami před sebou, když se z tohoto ohledu s jinými, často i menšími a slabšími národy srovnáváme. Od několika století pěstuje a vzdělává se národní starotinověda nejen ve Vlaších, Francouzích, v Anglii ale i v Němcích, v Dánsku, v Norvegii, ve Švédsku s nejstkvělejším prospěchem. Slavská Archaeologie naproti tomu jest ještě v kolébce a plénkách: a předce bez poznání národních starožitností nejen žádná jiná národní věda zrůstu a zdaru nemá, ale vůbec i pravá národní vzdělanost možná není. Bez vědy starotin není možný ani národní dějepis, ani starý zeměpis národu, ovšem pak národní mythologie; nebo všechny tyto vědy na oné, jako na základu, spočívají. Tak jako všecky vědy, nauky a umění sobě vespolek př́ibuzny jsou a teprv spoluvzaté jeden celek způsobují: tak jest to i s mnohými a rozličnými slavjanskými kmeny a jejich nářečími, dějinami, náboženstvími a bájeslovími a jinými výjevy života. Život jednoho kmene propůjčuje životu druhého kmene světla, jasnosti a souvislosti, byt' pak by je i čas a prostranství jakkoli mezi sebou loučili. Staroitalská Archaeologie a mythologie podává nám k mythologiem všech ostatních slavských kmenů klíče, odůvodňuje jejich jistotu a odstraňuje mnohé zbytečné pochybnosti a hádky, tak k. p. etruská a volská mythologie slouží za vítěznou obranu oněch pověstných od 
Levecova a jiných Germanů v pochybnost braných, ovšem za podvržené vyhlášených retranských, v Prilvicech vykopaných, a od Maše vydaných model, bohů a posvátných nářadí. Zde i tam, u Bodriců polabských a u Etrusků i Volsků italských, tytéž formy model, ti samí nápisové a zůstatkové řeči, anobrž ta samá, u jiných národů neobyčejná, míšenina kovu, mosaze a stř́ibra. Mnohé látky a sbírky, jako prvotiny k budově slavské Archaeologie nalezají se arci již ve spisech Lelevela, Chodakovského. Volanského, Köppena, Karamzina, Šafaříka, Vocela, Grolmusa, Vuka, Kukuljeviće, Gaje, mnoho i u Maše, Potockého, německých chronistů, Saxa Grammatika, Helmolda. Předce ale ještě leží zde ladem pole veliké; veliká a krásná zahrada zůstává a čeká tu ještě, aby očištěná, pokopaná, kvítím a stromovím vysazená a ozdobená byla. Ovšem že zde nejde tak o nádherná umělecká díla, jejich dokonalost a ušlechtilost, nýbrž mnohem více o to, jak dalece a hluboce slavský živel ve Staroitalii s bezpečností stopovati a odkrýti lze? Svrchovaná dokonalost, čarovná krása, rozmanité outvary řeckého a římského umělectví, byly příčinou, že za celá století skoumání starožitností téměř jen na klasickou antiku se obmezovalo. Starotiny dávných Slávů vůbec a pokrevných jim kmenů ve Staroitálii, Etrusků, Umbrů, Opsků, Volsků obzvláště, stojí arci, co do umělecké ceny, pozadu za sochami, řezbami, litinami, medaliemi a jinými pomníky Řeků, aniž propůjčují onen okoslepný pohled jako díla Apellesa, Praxitellesa, Lisiáše a jiných. Jejich platnost ale jest předce pro nás Slavjany neocenitelná, a tím dražší, čím více se v novějších časích ukazuje, že nejen Římané, ale i Hellenové mnohým věcem se od staroitalských národů, jmenovitě Etrusků naučili, neb již hotové od nich přijali. V těchto pozůstatcích a rumích umění a jazyka, byt' sebe chatrnějšími býti se zdály, jeví se předce duch, spůsob cítění a myšlení, celá povaha našeho národu. Proto každý Slavjan, jenž se národní vzdělaností honositi chce, musí toto drahé poručenství starobylých věků, tomu národu, jemuž ono nejsvětějším právem dědictví náleží, přivlastňovati, chrániti a brániti, v dobrém stavu zachovávati a známost o nich, zvlášt mezi bratřími, rozšiřovat hleděti.

V těchto našich starožitnostech nenaleznete ani žádných obšírných a stkvoucích opisů vítězství, krvavých válek a porážek, triumfů a podmanění cizých národů, jako u Řeků a jejich následovníků, polozhelenizovaných Římanů: nýbrž větším dílem jen tiché představení domácího, občanského a náboženského živobytí. Ale váleční skutkové jsou zř́d ka výtoky svobodné vůle národu, oni nejsou jistá znamení vnitřní národní hodnosti, oni vypravují toliko činy vůdců a panovníků. Mnohem pravěji a jasněji vysvítá tento z líčení mravů a zvyků, prácí a zaneprázdnění lidu samého, jeho svátků, slavností a obřadů: poněvádž se v nich duchovní ráz a pohled života nejčistěji a nejpřirozeněji vyráží. Slovem já a naše věda nepovede vás na krvavé bojiště, ani do bleskuplných Pantheonů, Atheneů, ne ku úžas vzbuzujícím pyramidám a kolosům: ale nejvíce jen ke truchlým zř́iceninám, zasypaninám, zlomkům a tmavým hrobům. - Nebo zdá se, praví jeden z našich starotinoskumců, že vyšší vůle světoducha tomu chtěla, aby, ant' jiní, často mnohem menší a nepatrnější národové v Europě a v Asii, skrze jejich válečné půtky s Řeky a Římany, místa sobě v dějinách světa vydobyli - utekla se stará a nejstarší historie Slávů do hrobů a podzemních skrýší; ale k těmto hrobům připojena jest myšlénka a náděje budoucího vzkř́íšení a nového velikánského života.

Toto cítí s radostí a s hrdostí každý, komu památka jeho předků, komu čest toho lidu, jehož synem jest, komu historická vážnost a světodějinná sláva toho národu, k němuž patří, na srdci leží. Proto, milí pánové! nedivte se nad skrovným snad ještě počtem posluchačů a milovníků slavské Archaeologie. Činí to novost této vědy mezi námi. Ona není věda chleba a ouřadu, ale čisté, svobodné studium vlastní a národní vzdělanosti, věda ducha, krásocitu a vkusu. Toto ale nemá naši lásku a horlivost oslabiti, tak jako to ani mou neoslabí; byt' pak i nemnozí, ale opravdoví ctitelé a posluchači této vědy zde přítomni byli, plní obliby a pozornosti k ní, tedy budu s takovým kocháním a nadšením o této vědě mluviti, jako bych plnou sluchárnu před sebou měl.

Ale nejen nová jest věda Archaeologie, obzvláště slavská, nýbrž jest ona i př́ijemna, a jedno z nejsladších a nejrozkošnějších zaneprázdnění již samo v sobě. Pamatuji se, že jsem v životopisu jednoho vlaského archaeologa, tuším Vermiglioliho, četl, že jen co obyčejný soukromní učený, v tiché samotě, často i v nouzi a potřebě živ byl. Když papež o jeho výborných spisech a archaeologických prácech slyšel a takové s podivením četl, psal onomu Archaeologovi, aby do Řima přišel, že jej bud' na biskupství, bud' na kardinálství povýší. Vermiglioli odpověděl na to Svatému Otci: že se za tuto milost poděkuje a Svatého Otce jediné o to prosí, aby jej zanechal při jeho dolcissimi studii archaeologici, t. j. při nejsladší vědě starožitnostenské. Správce církve rozuměl této prosbě a cítil celou její váhu, proto ji i naplnil tím, že onomu Archaeologovi roční podporu propůjčil. Vlaskému tomu zpytateli starožitností byla věda tato milejší a př́íjemnější, nežli bohaté důchodky, nádherné titule a vysoké ouřady. A jakž ne? Cele nový svět otvírá se zde jako skrze čáry a kouzla, před očima našima: skrze hroby jako skrze okna spatřujeme zde bohatý znamenitý život celých rodin, krajin a ř́ší; naše ucho slyší zde zvuky a slova naší mateřské řeči, jako ona před tisíci, anobrž dvěma, třemi tisíci lety zněla; naše oko vidí zde předhistorické zbořené př́ibytky, chrámy, bohy, nádoby, zbroje, peníze, umělecká díla a jiné památky rukami našich otců a praotců udělané, těch otců a předků, které pyšní Řekové co barbary považovali a opovrhovali. Zde se samovidně přesvědčujeme o tom, že naši předkové ve mnohém ohledu právě učitelé pyšných Helenů 
byli, a že tito nad ony sotva jinou přednost měli, než přednost štěstí. Radujeli se dítě, když nějakou pohádku rozřešiti a uhodnouti může: i jak žeby se Archaeolog neměl radovati, když se mu zdaří tu největší a nejzajímavější pohádku rozlouštiti, odkrýti vyjasniti a ku zřejmé názornosti přivésti, totiž pohádku života lidského, života národního? - Jeli to př́jemný cit pro lidomila, an vidí, jak to daleko věda vychovávání a vyučování v našich dnech přivedla, že i hluchoněmí mluviti mohou, že lze se s nimi dokonale porozuměti a jejich myšlénky i city prostředkem jistých znamení a slov uhodnouti a vyjeviti: i jakžby Archaeolog plesati neměl, když s celými velkými, zmizelými a oněmělými národy a krajinami, prostředkem pozůstatků řeči a nápisů mluviti může, které se ještě štastnou náhodou zachovaly? - Nebo ovšem při všech starožitnostech jsou a zůstanou nápisové a literaturní zlomkové veždy nejdůležitější a nejpamátnější. Oni jsou jazykem Archaeologie, oni jsou ještě posud žijící, a proto i nejhodnověrnější, očití a ušní svědkové dávno minulých národů a řečí; oni jsou tlumači a vykládači samých starožitností. Etruská aneb nolanská vása, modla aneb socha bez nápisu jest jako cele němý člověk, byt' pak tento byl sebe krásnějším, my jemu nerozumíme. Proto i staří nápisové a řeči největší pozornost a nejbedlivější pilnost Archaeologa zasluhují. Chvála Bohu! ve Staroitálii, jako jste to již Vy sami, milí pánové, v přednáškách o slavo etruských starožitnostech a nápisech minulého léta viděli a slyšeli, máme takových ochráněných a nalezených pozůstatků řeči veliké množství. Byla-li Etruria bohatá na nápisy a pozůstatky řeči: tedy Umbria jest ještě bohatší a snad ještě důležitější a zanímavější, jmenovitě pro ony slavné veliké Tabule Iguvinské, jichž v počtu 7 jest, které před několika stoletími v horách Apeninských v městě Iguvium (nyní Gubbio) vykopány a nalezeny byly v jednom zemětřesením propadlém a zasypaném chrámě; ony opsání bohů a bohyň, též i obětí, obřadů a svátků jim patřících obsahují, a mají nyní býti hlavním obsahem našich archaeologických přednášek. Mnohé z těchto nápisů já sám sem shromáždil, přeložil, vysvětlil, se slavjančinou srovnával a nalezl jsem, že i tito, tak jako etruské a opské, co doplňující díl staroslavské literatury považovány býti musejí. Oni jsou naši nejstarší a nejdražší pokladové.

Ti páni a Slávové, kteři již v minulém půlletí naše přednášky o Archaeologii vůbec a zvláště o etruských starožitnostech slyšeli, nyní již přirozeným způsobem všecko snadněji chápati budou; a však i ti, jenž nováčkové v této vědě jsou, at proto malomyslnými se nestanou; budu se vynasnažovati i je tam přivésti, aby se

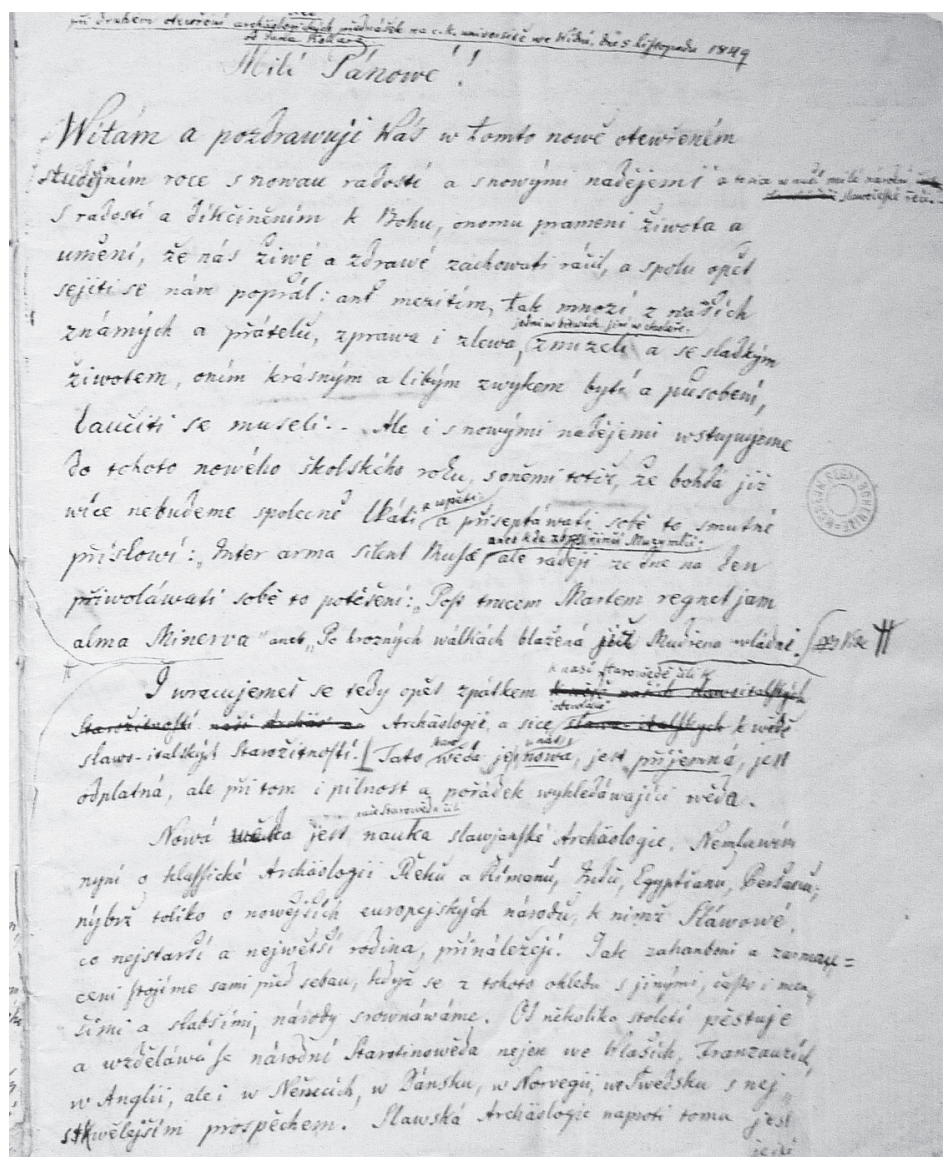

Obr. 6. Kollárův rukopis řeči z 5. 11. 1849. - Fig. 6. Kollár's manuscript of the speech from 5 November 1849. 
naučili nejen na vlastních nohách státi, ale i dále pokračovati. Proto, milí páni! považujte mne ne tak jako učitele v př́sném smyslu toho slova, nýbrž ráději jen co literního př́tele, co vůdce a rádce při vašich vlastních archaeologických studiech. Onino nádherně sobě počínající ouřední posunkové tvářnosti a školská katederní vysokomyslnost jsou mne cele cizí: já sám jich vystáti nemohu, zvláště u prostřed dospělých posluchačů.

U staroitalských národů panoval jeden pronikavý obyčej, který na jednom utěšeném etruském pomníku krásně představený a vyobrazený nalezáme (viz Gori Mon. Etr. 3. 2. 90). Totiž, když některý domácí otec smrti blízký byl a na smrtelné posteli jakoby v posledních tazích a okamženích se nacházel: tu matka vzavši syny své a dítky za ruce vedla je $\mathrm{k}$ lůžku rozžehnávajícího se otce; dítky naklonivše hlavy své ku hlavě a úst svých k ústům zemírajícího otce, vdechli ještě a vpili jakoby do sebe jeho loučícího se ducha, aby tento v nich i po smrti otce žil a působil. - Volnoli nové se starým srovnávati: považujte Vy tuto katedru co etruskou smrtelnou postel, mně a můj věk co onoho brzi loučiti se majícího otce; sebe pak, milí pánové, co podobné oněm slavo-etruským synům a potomkům. Co já zde jen počínám, klestím a připravuji, to vy budoucně v mém duchu dále ved'te a dokonejte. Nebo to jest osud člověčenstva: jedni odcházejí, jiní přicházejí; na ramenách předešlých pokolení vstupují, pozdější vždy výše a výše, až veliký neviditelný chrám vzdělanosti ducha, věd a umění tak vysoký bude, že nebe dosáhne a nám odtud výhled do nekonečnosti a věčnosti otevře.

\section{Př́loha 3.}

Jan Kollár: Závěr zimního semestru 1849-50

(předneseno na jaře 1850, před 5. dubnem)

\section{Appendix 3. \\ Jan Kollár: Conclusion of the winter semester of 1849-50 \\ (delivered in the spring of 1850, before 5 April)}

(Rukopis: Literární archiv Památníku národního písemnictví, Praha, fond Jan Kollár.)

\section{Milí Pánové!}

A tak již, s pomocí boží, končíme první polovici běžícího universitního čili učebního roku, a tím i slíbené přednášky o umbrických literních památkách jmenovitě o tabulích Iguvinských, těchto nejstarších a nejpamátnějších pozůstatků slavoeuropejského duchov/ního/života.

Ještě jest ovšem mnohé co bych Vám o umbrických a Iguv. tab. sděliti měl: ale cíl zdejších př̌ednášek není a nemůže být vyvážení a vyčerpání celosti a všech studnic této vědy: nýbrž toliko ukázání a proklestění cesty Vám k tomu; jen dávání návěšti a rady jakoby jste Vy sami ve velebné této vědě dále pokračovati, chut a smysl k ní v našem národu vzbuzovati a rozšiřovati mohli a měli.

A proto zůstaňte aspoň vy stálí a věrní této vznešené vědě, jak v mladším tak i ve starším věku anobrž v celém životě, a budte netoliko její milovníci a ctitelé, ale i její apoštolé a hlasatelé mezi jinými netečnými syny našeho národu. Vabte dělníky a volejte žence na toto pole k pilnosti a pracovitosti, nebo i zde: žeň jest veliká, ale dělníků málo.

Že posud tak skrovný počet ještě účastníků na této vědě podíl béře, to ovšem smutné znamení pro vzdělanost našeho národu. Mezitím to nás v předsevzetí mýliti nesmí. Věda tato není chlebová, ale duševní, krasocitná, svobodná, ona je nová a mladá, jejíž kvítky teprv do zahrady života vštěpovati začínáme: ba věru v povaze samé věci to leží, že nemnozí, že jen vyvolení podíl na ní s celým srdcem bráti mohou.

Na Umbry a umbrické nářečí následují nyní Oskové čili oské a sabinské nářečí. I toto má hojnou literaturu, drahé a znamenité poklady, a bude těm, kteři již umbrického nářečí známost mají, tím srozumitelnější a snadnějš́í. /.../ Po skončení italských památek a starožitností budou následovati drahocené starožitnosti Retranské, jejich vyobrazení, čtení a vysvětlení jejich nápisů a dokázání toho že nikoli podvržené, jako se někteří svedeni byvše Němci domnívali, ale ovšem pravé, čistoslovanské jsou. Laskavé nebe uděl nám k tomu zdraví a síly, národu našemu štěstí a slávy!

/Přípis rudkou:/ Přednášky se opět začnou dne 5 Dubna při /.../ 


\title{
Příloha 4.
}

Jan Kollár: Závěr letního semestru 1850

(předneseno v létě 1850)

\author{
Appendix 4. \\ Jan Kollár: Conclusion of the summer semester 1850 \\ (delivered in the summer of 1850)
}

(Rukopis: Literární archiv Památníku národního písemnictví, Praha, fond Jan Kollár.)

\begin{abstract}
Milí Pánové!
S tímto tedy již s pomocí boží končíme a zavíráme i druhou polovici studijního čili universitního roku a s ním i slíbený cyklus našich archäologickch přednášek a opsko-sabinských literných památek, mezi nimiž byli, at' je ještě v krátkosti ohlavíme, Mezník Abelanský čili Cippus Abelanus, obsahující vzájemné závazky mezi městem Nola a Abela co do polí, chrámu a pokladnice. Nápisy Herkulana a Pompeji, a to sice nápisy svaté na chrámích a sochách, nápisy občanské na veřejných staveních /.../. Nápisy slovan. na lebkách /= přilbách/ kovových ve Štyrsku nalezených a nyní ve zdejší sbírce starotin chovaných. Pak nápis Ortonský, obsahují/cí/ rozkaz o vážení chleba přezmenem a trestání těch jenžby váhu urazily. Nápis Capua Maritimský, čili Nařízení strany daní a poplatků u přístavu mořského od zboží dovezeného aneb vyvezeného. Zákony Tabule Bantinské záležející ze sedmi hlav čili kapitol. Konečně nápisy na nolanských nádobách čili paterách, vasách, urnách.

Arciže ještě mnoho pozůstává o opském kmenu v Staroitalii a jeho literních památkách, cožbych Vám sděliti měl a chtěl. Ještě zůstávají nejen mnozí nápisové, ale i celý zeměpis a místopis t. j. vysvětlení jmen místních, hor, oudolí, studnic, potoků, jezů, měst, a vesnic; - ještě pozůstává dějepis tohoto kmene, jeho panovníci a vůdcové, hrdinové, umělci ze slavského stanoviště považovaní. Ještě pozůstává mythologie čili bájesloví a srovnávání jeho bohů a bohyň s našimi staroslavskými.

Konečně Slovník všech posud známých opských slov v soustavný pořádek uvedený. Ale všechno toto nedá se v několika dnech a hodinách vykonati, ledaže povrchně běžně a lehkomyslně. Já pak nenávidím všelikou poloviční, zlomkovitou, povrchnou a ledabylou známost a vědu. K důkladné, ale hluboké a všestranné známosti potřebí času a práce pilné. - Mně nyní, jak Vám známo bude, pozývá vyšší uložení a povolání na cestu a sice archäologickou cestu do dalekých sice, a však někdy slovanských krajů a měst. Ten čas, který nyní ukrátiti přinucen jsem těmto přednáškám, proto pro vědu a národ náš nebude ztracen, ale jakž raději nám žádoucí ovoce přinese. Tak spojíme v naší Archäologii jih se severem, Staroitalii se Staro-Polabím a Pomořanskem, a jedno druhé se vespolek nahradí, doplní a vysvětlí.
\end{abstract}

\section{Příloha 5.}

Jan Kollár: Zahájení zimního semestru 1850-51

(předneseno v ř́jnu 1850)

\section{Appendix 5. \\ Jan Kollár: Beginning of the winter semester of 1850-51 \\ (delivered in October 1850)}

(Rukopis: Literární archiv Památníku národního písemnictví, Praha, fond Jan Kollár.)

\section{Meine Herrn}

Vielleicht wird es manchem unter Ihnen auffallend sein dass ich Sie heute deutsch anrede und begrüsse. Hören Sie also die Ursache davon. Zwei wichtiche Ursachen, zwei beherzigenswerthe Umstände nöthigen mich dazu dass ich, wenigstens für dieses Jahr noch, eine Ausnahme mache, und mich in meinen archäologischen Vorträgen einer Sprache bediene, die auch den Brüdern anderer Slavenstämme noch bekannter und geläufiger ist als der slavisch-čechische Dialekt, in welchem ich im vorigen Studien-Jahr den Versuch gemacht habe. Bei meinem besten Willen, überzeugte mich doch die Erfahrung davon, dass die Zeit noch nicht da sei, wo die slawische sprachliche Wechselseitigkeit bereits ins Leben getreten wäre - wir haben noch keine Schulen, keine Lehrer und Katheder an den Gymnasien, ja nicht einmal die nöthigen Bücher, Grammatiken und Lexica da. Verlangen wir also und erwarten keine Wunder auf einmal: es wird, es muss die Zeit auch 
diesen heissen Wunsch unserer Nation gewiss erfüllen. Aber Geduld müssen wir haben, Geduld mit uns und mit der Zeit.

Ich berufe mich in dieser Hinsicht auf wirkliche Thatsachen. Im vorigen Studien-Jahre hielt ich Vorlesungen in unserer čechischen Mundart. Anfangs meldeten sich und besuchten diese Vorträge auch Slavenbrüder anderer Mundarten, namentlich zwei Rusinen, ein Pole und ein Krainer wie sie sich selbst in dem Cataloge eingeschrieben haben. Einige Zeit nahmen sie auch wirklich fleissig Antheil an der Wissenschaft, gaben sich Mühe sowohl die ihnen neue Sache als auch die für sie neue Sprache zu erlernen: sie kamen oft zu mir, ich half nach; endlich überzeugte ich mich selbst von der Schwierigkeit - und da ich nun die einmal gewählte Vortragssprache, im Laufe des Semesters, nicht ändern konnte, so bleiben sie aus mit der Entschuldigung, das Böhmische verständen sie noch nicht vollkommen. Damit also alle Slavenbrüder offene Thür zu dieser Wissenschaft haben, ja damit selbst Nicht-Slaven falls sich welche fänden, Gelegenheit haben uns, und unsere Geschichte und Alterthumskunde kennen zu lernen: fand ich es für rathsam mit der Sprache wenigstens zu alterniren, und nicht plötzlich, sondern nur stufenweise, nach und nach, in ein ganz rein slawisches Element, in Form und Materie, zu übergehen.

Der zweite Umstand ist die Sache selbst, die in diesem Studien-Jahr zum Gegenstand unserer Vorträge dienen wird, nämlich die Rhetra-Prillwitzer Idole und die gesammte Mythologie der sogenannten Ost-seeslaven, die einst ganz Norddeutschland bewohnten. Diese Idole gehören der grossherzoglichen Mecklenburg-Strelitzischen Regierung an; sie liess solche untersuchen, sie lässt sie durch einen eigenen Mahler abbilden und lithographiren; sie hat mich beauftragt den Text und die Beschreibung dazu in der deutschen Sprache auszuarbeiten, um das Ganze in einer würdevollen Ausgabe dem Publikum zu übergeben. Und obwohl zwischen einem kurzen Text im Buche und zwischen einer Vorlesung im Hörsaale ein bedeutendes Unterschied sei: so stehen doch, dem Wesen nach, beide im innigsten Zusammenhange. Wähle ich nun zu diesem Behufe zwei Sprachen zugleich: so würde ich mit den Uebersetzungen aus einer Sprache in die andere wenigstens eben so viel Zeit verlieren, als die Forschung und Ausarbeitung selbst erheischt. Je älter aber der Mensch ist, je theurer muss ihm die noch übrige kurze Zeit sein. Falls mir Gott Leben und Gesundheit schenkt, so hoffe ich dass ich auch über dieses herrliche Palladium unserer Nation in der slawischen Sprache sprechen und schreiben werde. Und nur zur Sache selbst. -

\section{Př́loha 6.}

Jan Kollár: Poslední zahajovací přednáška slovanských starožitností na univerzitě ve Vídni v zimním semestru 1851-52

(přednesena 15. 10.1851)

\section{Appendix 6. \\ Jan Kollár: Final opening lecture of Slavic antiquities at the University of Vienna in the winter semester of 1851-52 \\ (delivered on 15 October 1851)}

Kollár, F. 1851: Př́mluva při otevření archäologických přednášek 15. ř́jna 1851 ve Vídni. Vesna (Vídeň) 1, č. 118 (25. 10. 1851), 487-488. (Rukopis chybi.)

Milí pánové! vstupujeme dnes opět do nového učebního roku začínajíce nový cyklus přednášek o slavské Starovědě, jmenovitě její nejdůležitější mythologicko-astronomické části. Mnozí professorové mají ten obyčej, že své přednášky s vychvalováním a oslavováním té vědy a nauky otvírají, kterou právě přednášeti chtějí. To pak dělají z dvojí příčiny, dílem aby vystavením důležitosti vědy nové posluchače vưkol sebe shromáždili a pro věc získali, dílem aby pozornost získaných již posluchačů a milovníků vědy ještě více napnuli a jejich pilnost živou a čilou zadrželi. I já bych mnoho, velmi mnoho ku chvále naší vědy přednésti mohl, mohl bych dlouhé panegyriky o Starovědě vủbec a o slavské obzvláště držeti: a však za zbytečné to držím, anat sama věda svou vlastní a nejlepší chvalořečnicí jest. Jen jedno chci, ne tak ku chvále jako raději k poroučení Starovědy, v duchu našeho Komenského (de cultura ingeniorum) a Herdera (Briefe zur Bel. der Hum.) rríci: „Starověda jest nejlepší základ čistolidské vzdělanosti a nejjistější cesta k poznání svého národu."

A tak jest v samém skutku; ona jest jako matka ostatních věd a umění. Jeli řečník, jeli básnír možný bez důkladné známosti dávných časů, starých náboženství, mravů a uměleckých výtvorů? Můželi umělec, malíŕ, řezbár̆, bez mnohostranné známosti starotin vyniknouti? Nepodáváli ona bohaté studnice a drahé poklady 
právníkům, bohoslovcům, jazykozpytcům, hvězdářům, mudrcům? Můželi lékař mnohé, mezi lidem panující, z pohanských časů zděděné pověry při nemocech a jich hojení pochopiti bez známosti starého náboženství a bájesloví? Nepropůjčujeli ona stavitelům a jiným řemeslníkům tisíce dokonalých vzorů a forem pro jejich díla? A co jest sám dějepis bez starovědeckých a bájeslovných studií? Pouhý materialismus, který se jedině událostmi a osobnostmi, vojnami a bitvami, jmény vůdců a panovníků, počty roků a století, slovem zevnitřními př́běhy, nikoli vnitřním hýbáním v minulých dobách člověčenstva zaneprazdňuje. Totot' ale jest toliko tělo, nikoli duše lidského života.

Ale slavská Starověda a s ní nejtužším svazkem spojené bájesloví zasluhuje naši obzvláštní pozornost. Ne proto, jakoby ona významnější byla nežli severní skandinavsko-germánská, aneb krásnější nežli řecká: ale proto, poněvadž pro nás syny Slavského národu, ohledem na národnost a místnost vyšší cenu a zanímavost míti musí, nežli kterákoli jiná. I ten, kdo ji ještě nezná, má příčinu domýšleti se, že ty idey, které představuje, v ní jiný, pro nás názornější oděv na se vzaly, nežli v jiných nám cizých mythologiech. Nebo náboženství jest nejušlechtilejší květ ducha národu a mythologie jest nejkrásnější a nejvlastnější národní poesie. Ona jest odblesk myšlenek, náboženských domnění a citů, důležitých pro každého, kdo se o bytí a žití, o činění a nechání, slovem o celém stavu svých předků poučiti žádá. A jestli naší mládeži, ovšem i dospělejšímu věku, mythologie Řeků a Římanů, Egyptčanů a Babylonských, Peršanů, Izraelitů a jiných národů cizí a neznámá zůstati nesmí: tím méně smí jim takovou zůstati Starověda a Bohověda vlastních otců a předků. Nebo kdoby chtěl jen v cizích domích známým a zkušeným býti a přitom vlastního domu a vlastních domácích neznati? -

Navzdor zajisté oné velké podobnosti, často totožnosti, která se v mythologiech starých národů nalezá: jest přece mezi nimi i znamenitá rozličnost, která se dílem ve přirozených každému kmenu vlohách zakládá, dílem vplyvem podnebí a jiných okolnosti zplozena aneb zvýšena jest. Nebo jak náboženství na lidi a národy veliký vplyv jeví: tak jest i na opak, i lidé a národové mají veliký vplyv na náboženství. Vida nejvyšší bytnosti sama v sobě, jest jedna a táž ve všech náboženstvích, u všech lidí a národů: ale způsob, kterým lidé tuto vidu v sobě poznávají, vzdělávají, uměleckými díly sobě stělesňují, jest tak rozmanitá jako národnosti a osobnosti. Každý národ zná jen sebe a př́rodu, v níž žije: jen ve formách a podobách této jeví se mu božství. Místnost a čas dávají jeho myšlénkám přirozené, viditelné roucha a jeho citům živou barvu. Slavská Mythologie jest též věda a to sic ne více zlomkovitá, nýbrž soustavná, okrouhlá, ohraničená, vlastní ráz na sobě nesoucí, někdy úplně vzdělaná věda, která co do bohatství a starobylosti sice ne indické, co do obrovské ohromnosti forem ne skandinavské, co do svrchované krásy a aesthetické klassičnosti ne řecké: než co co významnosti a hlubokosti, co do pravdy a nevinné prostoty, co do praktické důležitosti pro život se všemi těmi směle měřiti se může. Výtvory cizích mythologií musíme obdivovati, ony nás naplňují často jistým chladným úžasem: výtvory naší mythologie musíme milovati, ony nás naplňují teplou láskou již proto, že naše jsou. Ony ještě žijí, netoliko ve světě věd a umění, nýbrž i v skutečném životě, v národních zpěvích a povídkách, v národních obyčejích a půvěrčivostech, tak že o nich říci můžeme: ony jsou duch z ducha našeho, Zdali my pro tyto poklady závisti jiných hodni jsme čili nic, zdali přednost nad podobné sbírky a klénoty jiných národů zasluhují? jest jiná otázka, na kterou každý národ, citem samolásky veden, jinou a jinou odpověd' dá.

Nám bud' prozatím dosti na tom, že více než 200 skutečných výtvorů a památek Mythologie štastná náhoda aneb raději příznivá Prozřetelnost Slávskému národu ochránila a takové v našich časích na světlo vynesla. Jsou to ony slavné retranské modly, které v Prilvicích, zakopané v zemi, nalezeny byly a nyní v Novo-Strelicích se chovají. Jedenkaždý z nás poznej, ostříhej, zvelebuj toto nevyrovnané naše národní jmění a vlastnictví. Že pak toto jistotně naše jest a jméno všeslavského pokladu a dědictví zaslouží, jest svatá nepochybná pravda. Nedomnívejtež se zajisté, jakoby retranská mythologie jenom na Retru, aneb nejvýš na Pomořany, ostrov Ránu a Baltické moře obmezena byla: nikoli, ona jest střediště bohů všech slavských kmenů. Co staroslavská, v bibli a jiných rukopisech zachovaná řeč pro částečná slavská nářečí jest, to jest retranská mythologie pro částečné mythologie slavských kmenů; všickni se zde shledají, potkávají, sestřed'ují. Retra nebyla ani kolébkou ani metropolí slavské mythologie, nýbrž toliko útočištěm, kde se slavopohanští bohové, ode všech stran pronásledovaní, skryli a kde, př́ćcinou polohy ostrovu a jezera Doleneckého a pevnosti Retry i déle i čistěji se udrželi, nežli v ostatních slavských krajích. Nakolik tedy Slávové jsme, natolik i retranské starožitnosti naším a všech Slávů vlastnictvím jsou. K poznání a vysvětlení bohů našich předků my již nepotřebujeme, jako jiní národové, cestou pouhých hypothes a domyslů kráčeti, aniž ze samých mutných a mrtvých studnic prostonárodních pověstí a báchorek čerpati, ze kterých nyní těžko, často nemožno, pravého smyslu se dopíditi. Naše studnice žijí, naši bohové vstali z mrtvých, oni mluvějí k nám řeč, kterou i my nejen rozumíme, ale i mluvíme. Ale netoliko naše historie a mythologie, nýbrž i táž sousedních národů, jmenovitě Němců, mnoho světla, doplnění a potvrzení získá skrze bohy z Retry, a čím pilněji a důkladněji němečtí učenci naše starotiny poznávati budou, tím spravedlivější a pravdivější bude i jejich soud o našich předcích. 
Než není dosti jen míti něco a tím jměním se snad před jinými chlubiti: my musíme tento, nám nebem daný dar i poznati, vysoce vážiti, do života uvesti a použíti, ovšem i jiné bratry k tomu probuzovati, aby radost naše dokonalá byla a aby se náš národ tohoto tak výborného daru i hodným býti dokázal. Nebo komu mnoho dáno, od toho se i mnoho žádá a očekává, ten jest povinen i počet složiti z toho, jak se svěřeným sobě pokladem těžil a hospodařil. Jeli nevděčnost již při jednotlivých lidech a při tělesných dobrodiních škaredým hříchem: čím více ona to býti musí při celých národech a při duchovních, vědeckých dařích a pokladech. Chut a smysl pro zpytování národních starožitnosti budí se sice nyní mezi všemi Slavy, jednoty a spoĺky ke hledání a ochránění dávných národních pomníků utvořují se téměř u všech našich spolukmenovců. Dobře zřízená Musea a soukromé sbírky otvírají svobodný přístup k mnohým starovědeckým pokladům zvědavému obecenstvu, tak v Praze, v Záhřebě, v Krakově, ve Lvově, ovšem i zde ve Vídni. Ale ještě mnoho z tohoto ohle-

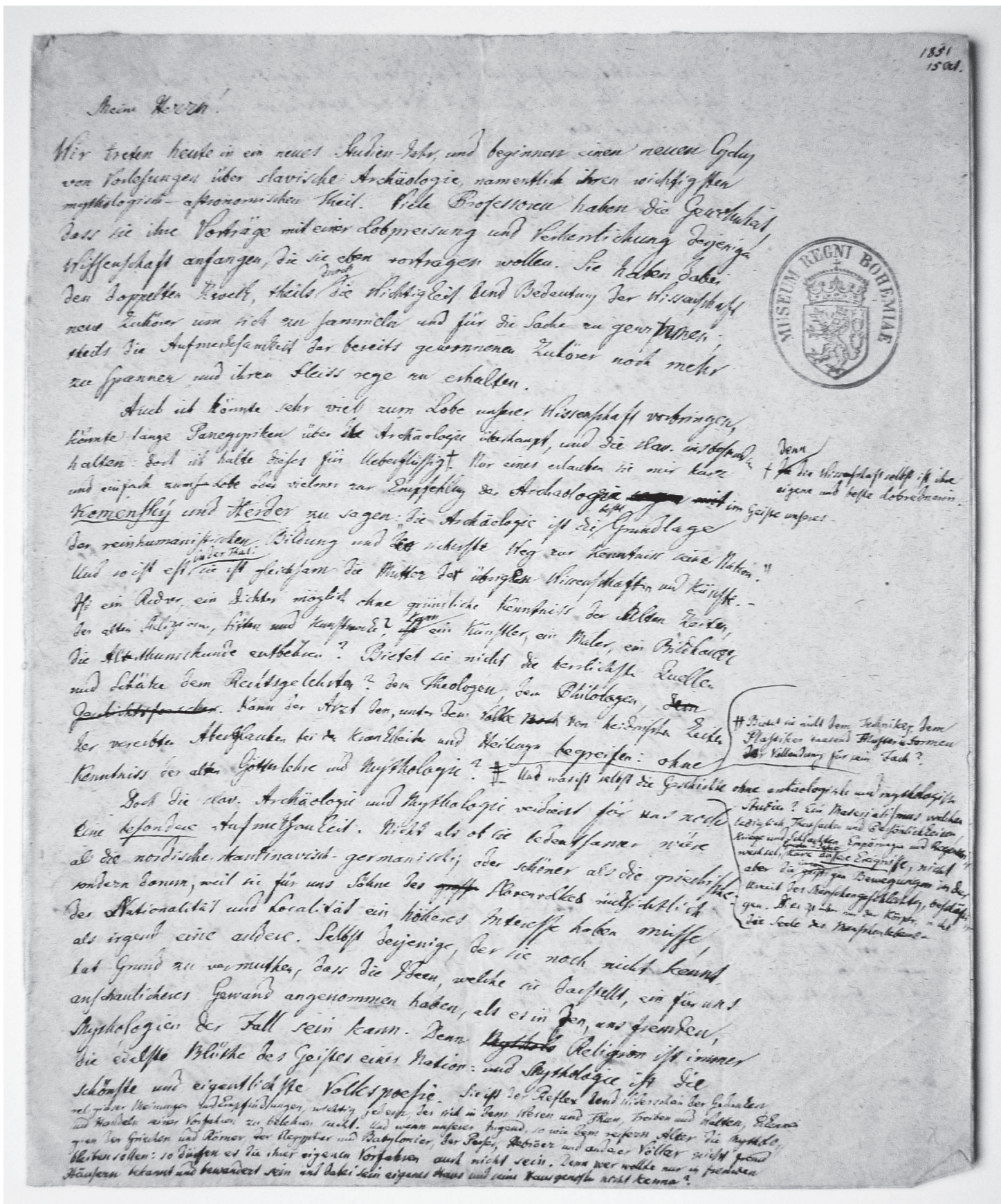

Obr. 7. Kollárův rukopis německé verze řeči z 15. 10. 1851. - Fig. 7. Kollár's manuscript of the German version of the speech from 15 October 1851. 


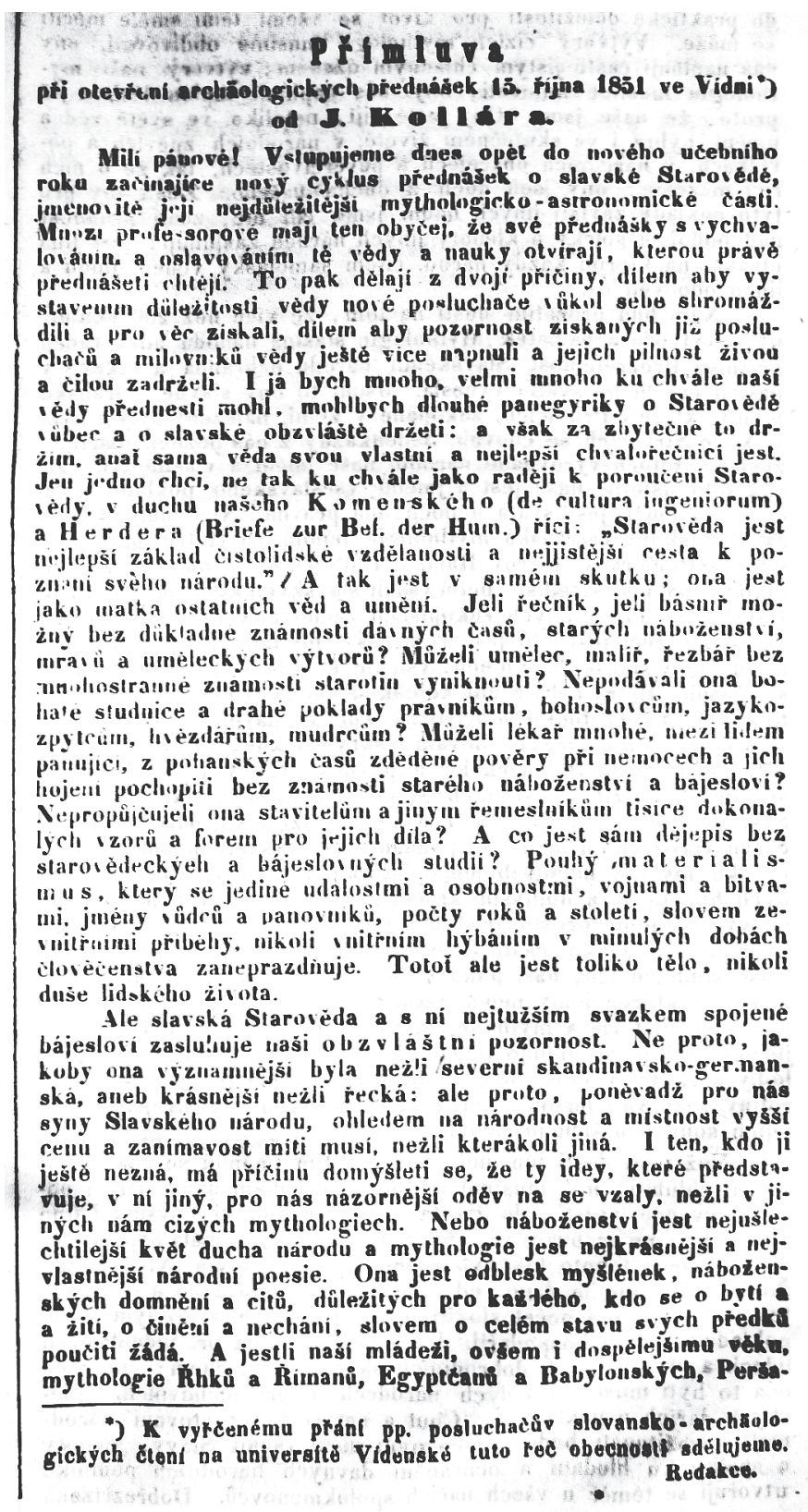

Obr. 8. Tisk české verze Kollárovy řeči z 15. 10. 1851 (Vesna 1, 1851, 487). - Abb. 8. Print of the Czech version of Kollár's speech from 15 October 1851 (Vesna 1, 1851, 487).

du k činění pozůstává. Ještě musejí samy vrchnosti tyto vážné starotiny pod ochranu vzíti, které neumělost a lehkomyslnost všetečně ničí aneb nízká zisku žádost ukrývá, slévá a v obyčejný kov a peníz obrací. Ještě musí naše Archäologie a Mythologie do škol, gymnasií a universit všeobecně co řádné studium uvedena býti; ještě musejí prostonárodní knihy o této vědě pospolitým jasným slohem sepsány a rozšiřovány býti, aby tyto poklady i obecnému lidu př́stupné byly a tak ze školy do života se přesadily a opravdovou národní vzdělanost umožnily a připravily. Nebo jen ta vzdělanost jest národní, pravá a trvanlivá, která se na kořenech a základech národní minulosti staví. A toto jest vaše úloha pánové! tato práce čeká na vás jako mladší pokolení našeho národu.

Čím větší jest počet těch, kteří pouze chlebodarnými vědami se zaměstknávají, nedbajíce na to, co čistolidského a čistonárodního jest: tím větší musí býti vaše učastnost v této vědě, tím snažnější vaše pilnost v ní již proto, že se Vám mezi nesčíslnými bratřími přece poštěstilo ze žaláře oné všednosti se vylámati a k vyššímu tomu svobodnému životu se povznésti. Bud'mež tedy netoliko posluchači a ochotníci této národní vědy, nýbrž i její učitelé a apoštolé mezi nevěřícími aneb odcizenými. Nedejte se mýliti v tomto vznešeném povolání ani 
křikem neznalců ani šeptem pokrytců a posměvačů, kteří Mythologii za dětinské bájky a hračky vyhlašují a v uponižování pohanství povyšování křestanství hledají. Kř̌estanského náboženství nelze ani chápati ani ceniti tomu, kdo nezná jeho předchůdců.

$\mathrm{V}$ minulém běhu bavili jsme se $\mathrm{v}$ našich archäologicko-mythologických hodinách více na zemi, při zemských božstvích a náboženských úkazích, chrámích, slavnostech, obětích; nyní zraky své více k nebesům a k obloze obrátíme, budouce považovati jeden z podivu nejhodnějších pozůstatkův našich předků, totiž tak řečený mythologicko-astronomický Zvíretník čili Zodiakus, a jeho spojení s rolnictvím a celým živobytím našich praotců Staroslavů.

\title{
Příloha 7. \\ Jan Erazim Vocel: Plán univerzitních archeologických přednášek v Praze (psán patrně již 1849)
}

\author{
Appendix 7. \\ Jan Erazim Vocel: Plan of the university archaeological lectures in Prague \\ (apparently already written down in 1849)
}

Vocel, F. E.: Programm der Vorlesungen über böhmische Archäologie und Kunstgeschichte von foh. Erasmus Wocel. (Nedatovaný rukopis-koncept, Státní okresní archiv Kutná Hora, fond J. E. Vocel.)

Als oberster Zweck der böhm. Alterthumskunde wird hingestellt: das Leben des böhm. Volkes in seiner Urzeit, insbesondere aber jene Seite desselben, durch welche sich das Streben nach dem Idealen und Göttlichen ankündigt, mit Hilfe alter Kunst- und Kulturdenkmale zu erforschen und darzustellen.

Die böhmische Alterthumskunde umfasst allerdings bloss ein Aggregat empirischer Erkenntnisse, erlangt aber durch die systematische Anwendung des zur Realisierung des obersten Zweckes dienenden Material einen wissenschaftlichen Charakter. Damit aber dieselbe als Wissenschaft ihrem Zwecke entsprechen könnte, ist es nothwendig, sie in zwei von einander unabhängige Abschnitte abzutheilen, und zwar:

1. Archäologie der vorchristlichen Periode Böhmens.

2. Archäologie des böhmischen Mittelalters.

Obgleich beide Theile dieser Wissenschaft einen und denselben Zweck anstreben, so sind doch die Mittel, deren sich die Archäologie im jeden dieser Abschnitte zur Erreichung ihres Zieles bedient, so verschieden von einander, dass sie unter einen Erkenntnissgrund sich nicht einreihen lassen. Denn die Kunst- und Kulturüberreste aus der heidnischen Periode Böhmens sind in das Dunkel des Zweifels und der Ungewissheit gehüllt, indem eine charakterisierende Unterscheidung zwischen keltischen, germanischen und slawischen Alterthümern in Böhmen noch nicht stattgefunden. Es ist somit die specielle Aufgabe der ersten Abtheilung der böhmischen Alterthumskunde, mit Hilfe der historischen Kritik, der vergleichenden Sprachen- und Völkerkunde jene Denkmale, welche die beiden erstgenannten Urvölker in Böhmen zurückgelassen, von den ältesten Kunst- und Kulturüberresten der Čechen zu sondern, die letzteren zu sichten und zu ordnen, um so dann aus denselben eine Darstellung des ältesten Zusammenlebens des böhmischen Volkes in kulturhistorischer, mythologischer und staatlicher Beziehung zu entwerfen.

Um diese keineswegs leichte Aufgabe zu lösen, ist ein tiefes Eingreifen in die älteste Geschichte der indoeuropäischer Völkerstämme erforderlich, ferner die Kenntnisse der entsprechenden Stellen der klassischen und byzantinischen Autoren, sowie zur Herstellung wichtiger Parallelen auch die der Quellenangaben über norddeutsche Geschichte des X., XI. und XII. Jahrhundertes. Auch darf bei den Vorträgen über diesen Theil der böhmischen Alterthumskunde nicht ausser Acht gelassen werden, dass, um die charakterisierten Nationaleigenthümlichkeiten der slavischen Böhmen hervorzuheben, eine immerwährende Rücksicht auf die ältesten historischen und Sprachquellen der übrigen slavischen Völker genommen werden muss. Endlich wird vorausgesetzt, dass zur fruchtreichen Förderung dieser Wissenschaft die etwa noch vorhandenen Kunst- und Kulturüberreste der heidnischen Periode zur unmittelbaren Anschauung vorgelegt werden müssen der Gefertigte die Hoffnung hegt, dass das löbl. Ausschuss des böhm. Museums nicht /škrtnuto Vocelem/

Die Alterthumskunde des böhmischen Mittelalters hat das Substrat ihrer Forschung, nämlich das böhm. Volk, historisch festgestellt und gegeben. Sie hat nicht nöthig, wie die Archäologie der heidnischen Periode, mit Hilfe der historischen Kritik, der ethnographischen und linguistischen Forschung, die Existenz der Kulturüberreste der heidnischen Epochen darzuthun und zu beweisen. Sie sucht blos auf und erforscht 
die Denkmale der Kultur und Kunst, und der geistigen Entwickelung der Böhmen überhaupt, vergleicht dieselben mit ähnlichen Monumenten anderer Nationen und liefert dadurch einen immer mehr sich häufenden Stoff zur treuen Darstellung des böhm. Volkslebens und zur gehörigen Würdigung eines Werthes in kulturhistorischer, nationaler und politischer Beziehung in den mannigfachen Perioden des Mittelalters. Während also die Archäologie der heidnischen Periode sich der historischen und ethnographischen Forschung als des Hauptmittels zur Analisirung ihres Zweckes bedienet, liegt das Hauptmoment der Thätigkeit der Archäologie des böhmischen Mittelalters in der Kunstkritik und in dem Kenntniss /.../Kunstdenkmale. Durch diese beiden Hilfsmittel wird die Eintheilung der böhm. Archäologie als Wissenschaft in die oben angeführten Abschnitte begründet.

Die Vorträge über die Archäologie des böhm. Mittelalters verbreiten sich über die Denkmale der Malerei, als: alte Miniaturen, Hand- und Tafelgemälde, ferner über die Monumente des byzantinischen, des Übergangs- und des gothischen Styles, der Skulpturen, Schnitzwerke usw. Dabei muss ein fortwährendes Kombiniren mit ausländischen, zumal deutschen und slavischen Kunstresten dieser verschiedenen Gattungen stattfinden. Ein ferneres Objekt der archäologischen Vorträge sind die ältesten böhm. Literaturdenkmale, zumal die der Dichtkunst. Diese sind nicht bloss ein Behelf- und Hilfsmittel zur Aufklärung und näherer Würdigung der plastischen Kunstdenkmale; sondern sie liefern in Verbindung mit den Kunstresten der Malerei, Plastiken, Baukunst zugleich die Materie, aus welcher sich ein naturwähres Bild des häuslichen und öffentlichen Lebens, der Kleidertracht, des Culturzustandes und der geistigen Anschauungs- und Denkweise der Böhmen darstellen lässt. Die Archäologie, so wie ich sie hier auffasse, hat nicht bloss für die Cultur- und Kunstgeschichte Böhmens eine grosse Wichtigkeit, sondern auch als Wissenschaft eine höhere Bedeutung. Denn der Zweck jeder Wissenschaft ist die Weckung und Förderung irgend einer Erkenntniss, mag diese nun dem Gebiete der sinnlichen Natur, oder der geistigen Potenz der Menschheit angehören, durch die Archäologie, in soferne dieselbe den Kulturzustand und das geistige Leben des böhm. Volkes schildert, wird die specielle Kenntniss eines Theiles der Menschheit gefördert, und zwar jenes Theiles der Menschheit, mit dem jene, für welche diese Vorträge bestimmt sind, als Söhne des edlen Böhmervolkes in nächster unmittelbarer Verbindung stehen.

Obgleich das Gebiet der hier zu behandelnden Wissenschaft ist von so grossen Ausdehnung, dass die Kräfte eines Einzelnen zur Lösung der schwierigen Aufgaben die sie aufstellt, kaum hinreichen, so lebe ich der festen Hoffnung, dass mir meine innige Liebe zum Vaterlande die Kraft geben und eine angeklärte Regierung die Aufmunterung und Hilfe nicht versagen wird, damit ich wenigstens den Grundstein legen kann zu einem wissenschaftlichen Gebäude, das von andern fähigern, durchgebildeteren Geistern in der Zukunft zur Ehre Böhmens und zur Verherrlichung der Wissenschaft in Österreich an der Hochschule Prags aufgeführt werden soll.

Meine Vorträge über böhmische Archäologie und Kunstgeschichte stellen sich daher in ihrer einfachsten Gliederung auf folgende Weise dar.

I. Archäologie der vorchistlichen Periode Böhmens.

A) Die Urzeit Böhmens.

B) Die Kelten. Charakteristik keltischer Alterth.

C) Die Markomanen. Charakteristik markom. Alterth.

D) Die Slaven. Charakteristik slav. Alterth. Die aus den Resultaten archäologischer Forschung construirten Bilder der ältesten Cultur, des häuslichen, kriegerischen und religiösen Lebens der heidnischen Böhmen.

II. Archäologie des böhmischen Mittelalters.

A) Übergang vom Heidenthum zur Christenthum; die Spuren derselben in den ältesten Culturüberresten.

B) Nationale Epoche der böhm. Kunst (bis zur Mitte des XIII Jahrhundertes) a/ Dichtung, b/ Malerei, c/ Baukunst und Skulptur

C) Zweite Epoche der böhmischen Kunst

D) Darstellung des geistigen, häuslichen und socialen Lebens der Böhmen in der Nationalepoche des böhm. Mittelalters

E) Darstellung des Lebens der Böhmen seit der Mitte des XIII Jahrhundertes bis auf Ferdinand I.

F) Schlussbetrachtungen. 


\title{
Př́loha 8.
}

Jan Erazim Vocel: Programový úvod k přednášce o archeologii pohanského věku (předneseno 10. 4. 1850) 14

\section{Appendix 8. Jan Erazim Vocel: Programme introduction to the lecture on the archaeology of the Pagan Age (delivered on 10 April 1850)}

\author{
a/Wocel, f. E.: Úvod k přednášení o archeologii české. (Nedatovaný rukopis: Státní okresní archiv Kutná Hora, fond \\ f. E. Vocel) \\ b/Wocel, f. E. 1850a: Účel a význam archeologie české. Časopis Národního muzea 24, 115-126.
}

\{Považuji to za zvláštní přízeň osudu, Pánové! že mně prvnímu popřáno jest, na vysokých školách pražských přednášeti českou archeologii, vědu, která s životem naším v úzkém spojení se nalezá. protož skládám povinné díky J. Vel. císaři a králi i vys. ministerstvu osvěty za zřízení professury české starovědy, taktéž i slavn. sboru professorův fakulty filosofické, kterýžto mne k tomuto, pro národní vzdělání důležitému úřadu navrhnul.\}

Probuzený duch národnosti [Historická důstojnost národa] žádá, aby národ poznal sám sebe. Nenít pak národ pouze za nynější doby žijící pokolení jednoho jazyka a rázu; nikoli, slovo „národ“ zahrnuje významem svým též i dávno zhaslá pokolení, z jichžto krve, jazyka, ducha, mravů, strastí i slastí nynější potomstvo zrostlo a se vyvinulo. Tak i národ český obsahuje v sobě veškerá pokolení krve české od pradávných dob, k nimžto světlo historické ani paprsky svými nevniká, až k pokolení nynějšímu. \{Od nejdávnějších časů zjevuje se jeden atýž český národní živel; doby a stupně vyvinování jeho jsout ovšem rozmanité, avšak národ jest jeden, nerozdílný.\} Protož se zakládá na slávě získané za minulých časů též i sláva národní v době nynější. \{Skutek skvělý, bud' si on rekovností aneb v oboru umění, věd a lidské vzdělanosti vůbec duchem českým vykonán, nesmí tudíž ztracen býti z paměti potomkův, nýbrž co majetnost národní musí vložen býti mezi klenoty, jimiž národ náš na budoucí časy se zdobiti a honositi má.\} V hojnosti a skvělosti těchto pokladů objevuje se historická cena veškerého národa. Národ, jenž sobě nevšímá a neváží pokladů takových, bud' jich naprosto nemá aneb tak hluboce klesl, že jemu čest a hana, sláva a ponížení věci lhostejné jsou, že lopotíc se v podlém soběctví ani neznamená, kterak se od velebného, božského původu svého odchyluje a k podlému zvířectví kloní. Běda národu, jenž zaslepen jsa kouzelnou vnadou jakékoli světoběžné idey, k takovéto samovraždě by se naklonil! Byt' i zhasla pověst bývalé slávy jeho, pamět hanby nové zůstala by na věky!

A bohužel! musíme se vyznati, že jsme se my Čechoslované jižjiž k oné době smrtné mrákoty klonili; nebo větší díl vzdělanců kmene českoslovanského děje a jazyk předkův a svou vlastní národnost za povrhel považovali, tomu napomáhajíce, aby tato násilně dušena a ze života vypuzena byla. Národní rovnoprávnost slovem císarským veškerým Rakouska národům za heslo spásy ustanovená, zahnala onu mrákotu a národ náš k novému naděje plnému životu vzkř́ísila!

Dějepis, jenž líčí osudy a skutky člověčenstva, vede tím samým k poznání života národův. „Jen tam, kde ušlechtilejší částka člověka vládne nad oborem činnosti pouze zvířecí, kde život lidský touhou po ideách a bohovosti nabývá významu vyššcho, a duch ani v kalu tupé všednosti netone, ani jedem přebroušené smyslnosti se nevysiluje, kde jméno boha a vlasti, zákonův a cnosti, práva i svobody budí v duších takový ohlas, že obec celá hotova bývá i krví svou o ně se zasazovati: jen tam díti se mohou skutkové, které připomínati potomstvu i milo i hodno jest." Takto dí náš Palacký v úvodu svém k dějinám českým. - Ukazujet' ovšem dějepis, kterak národ touhu svou po ideách a bohovosti projevuje; avšak jen potud důkazy toho podává, dokud tyto do života veřejného, politického neb válečného zasahují. Důkazy však vznešené této touhy, které se v tiché domácnosti, v oboru umění, náboženských obřadů a vzdělanosti vůbec vyskytují, dějepis, zvláště dávnějších věků, jen velmi zřídka obsahuje. A předce ona duševního snažení stránka, jež se nezjevuje ve hluku osudných dějů, nýbrž v tiché soukromnosti se tají, nad míru důležitá jest. Tak n. př. drahocenné ostatky z dávných věků, v rukopisu Králodvorském nám zachované, obrazy karlotýnské, vzácné to památky umění českého XIV století, neméně národ náš oslavují, nežli jakýkoli válečný skutek předků našich, jejž dějepis v desky své zaznamenal.

\footnotetext{
14 Základním textem je rukopis /a/, do něhož jsou zaneseny (kromě interpunkčních apod. drobností) změny provedené Vocelem pro tisk /b/ - není známo, zda před přednesením na univerzitě nebo až před tiskem: $\mathrm{v}$ závorkách [ ] jsou umístěny změny proti původnímu textu, \{ \} nové rozšiřující vložky; škrty v původním textu jsou ponechány, ale označeny. V lomítkách // místa výjimečně vypuštěná editorem. Zdůraznění slov a vět pochází z tisku /b/.
} 
Archeologie národní, jenž nám život duševní dávných věků prostředkem uměleckých památek otvírá, jest tudíž bez odporu jedna z nejdůležitějších věd, [stojí tudíž bez odporu v první řadě věd,] kteréžto národnímu dějepisu k vykonání vznešené úlohy jeho nápomocny jsou.

Jednát ovšem národní archeologie o starobylostech; avšak vším právem tvrditi se může, že jest nejmladší věda, jižto duch času zplodil, jelikož právě ve hnutí národním nynějšího věku původ a počátek svůj béře. Před několika desetiletími [V nedávno minulé době] ještě obsahovala archeologie nejvíce známost řeckých, římských, egyptských a hetrurských starožitností, a jen nějaká mimochodem zmínka se činila o památkách germanských a keltických [celtických]; o slovanských však (zde nemluvím o starožitnostech jazykových a národopisních) jen velmi zř́ídka nějaká suchopárná správa byla prohozena. Souvisely ovšem starobylé umělecké památky klasických národů s klasickou literaturou, přičiněním humanistů pilně vzdělávanou. Mimo to poskytovaly ostatky starobylého umění na klasické italské a řecké půdě nalezené výtečností svou skvělý pohled a protož se co drahocenné šperky sestavovaly ve sbírkách veřejných i ve skříních zámožných příznivcủ umění, kdežto starobylosti keltické [celtické], germanské a slovanské z velké části neouhledné jsouce, opovrženy a zapomenuty zůstaly.

Nicméně v těchto ostatcích, z pradávných dob až ke dnům našim zachovaných, velká cena se skrývá, stavíc je mnohem výše každému národ svůj milujícímu vzdělanci, nežli sebe skvělejší umělecké zbytky dávných Řeků a Egyptčanů. Starobylosti národní vysvětlují spůsoby, obyčeje, náboženské obřady, stupeň umění a vzdělanosti dávných předků našich, o nichž historie bud'to pražádné aneb mylné správy podává. Nebot' starý dějepis líčí nejvíce válečné činy; o národu, jenž krvavých stop v letopisech nezanechal, mlčí historie naprosto aneb jen tolik o něm se zmiňuje, aby jménem jeho nějaká mezera na mapě národopisné vyplněna byla.

$\{\mathrm{K}$ tomu přistupuje, že o dávních dobách evropejské historie nejvíce správy se vážily z řeckých a římských spisovatelů, zmiňujících se pouze o takových národech, $\mathrm{k}$ nimžto válečná zbraň světovládných Ř́manů zasahovala. Kdyby výbojný meč Římanův s kopím germanským se nebyl setkal, sotva by se nějaké správy nalezlo o Germanech u Julia Caesara a Tacita: historie Germanů by bez pochyby hustou mlhou byla zahalena podobně jako děje Slovanů, o nichžto na jihu historie řecká (byzatinská) a na severu dějepis německý jen potud vypravují, dokud se Slovanstvo s těmito národy na krvavém dějišti potkalo.\}

Jestito velká, ovšem i nesnadná úloha, děje, mravy a obyčeje pradávných mlhou krytých národů [úloha vědy historické, netoliko boje národův a skutky velitelův jich, nýbrž i snažení a činnost lidu líčiti, pradávnou, až posud mlhami zatajenou historii vzdělanosti a mravů] světlem a barvou přiodíti a umrtvělé tvary nejstaršího národního života proniknouti duchem vědeckým. Předních prostředkův k dosažení cíle tohoto poskytuje vyprávění starých letopisů [zpytování starých archivů a letopisů]; taktéž čerpati lze, ovšem opatrně, z národních pověstí a podání; a kde i tyto prameny vysychají, poskytuje srovnávající jazykozpyt obezřetnému badateli světla; a když i toto zhasne, zableskne, ovšem děsným světlem - poslední historická jiskra z hrobů dávno zhaslých pokolení. \{Což n. p. nám Čechům osudem dochováno jest z pohanských dob předkův našich? Ozývát se líbezný avšak temný hlahol oněch časů v Králodvorském rukopise, jako milohlasná ozvěna sladké písně posledního slavíka; a však tážeme-li se ducha historie a básnictví po dalších dřevnějších správách, tut žádné odpovědi již neobdržíme. - Než však ejhle!\} Ve hrobích pohanských zjevují se vojínové [bohatýři], mající meče a kopí po boku [meče po boku, kopí v rukou], řízu sepiatou překrásným spínadlem, rámě a nohy zdobené broncovými [bronzovými] kruhy. Tyto hrobové ostatky dávají nám ovšem němé, avšak makavé svědectví o zbrani, kroji a o stupni umělecké a řemeslnické [umělecké] vzdělanosti předkův našich, k nimžto světlo historické [světla historického] více nevniká. Tak na př. v přehojných rovech, ježto rozbouřené Labe před několika lety odkrylo, objevuje se množství z velké části vkusně a ozdobně zhotovených nádob a osudí, jenž popelem mrtvých a ostatky domácího zaměstnání naplněny byvše, svědectví dávají o řemeslnické a umělecké zběhlosti a o pohřebních obřadech Čechův, věku Přemyslovu a Neklanovu současných. Ano, tvrditi můžeme, že duch zpytující pronikna temnost hrobů velí, aby dávné věky z mrtvých vstaly - tvrditi můžeme, že se zde myšlénka vzkř́íšní vyskytuje ve skutečném spojení s hrobem! - -

Avšak tajiti nemohu, kterak nesnadné jest zpytování takové, kterak bludu a klamu na mnoze podrobeno. Nelze nabýti dokonalé známosti starobylostí žádnému bez porovnání jich s památkami druhu tohoto ostatních europejských, zvláště pak jinoslovanských národů. Ba věda archeologická vzdělavatele svého až za vzdálený ocean na pevninu Ameriky odkazuje, kde se na ohromné prostoře od moře Atlantského až ku břehu řeky Misisipy nesčíslné množství rovů vyskytá, jichžto obsah se na mnoze podobá ostatkům věků pohanských, jenž se na půdě střední Evropy objevily. Zjevuje se tak patrná příbuznost pohřebních obřadů, a tím svědectví o příbuznosti kmene, zjevují se tajnosti národopisné, o nichžto jsme potud žádného tušení neměli.

Podobně jako starobylosti poskytují historii vítané pomoci k dobývání pravdy dějepisní, taktéž dějepis podává archeologii hlavní základ, na němž tato soustavu svou může stavěti. Věda archeologická v nejužším spojení s historií se nalezá, nemohouc se obejíti bez podrobné známosti jednotlivých historických věků. 
Zvláště to platí o archeologii české. Na půdě české vyskytují se v pradávné době tři národové, totiž: keltický [celtický] (čili vlaský), germanský a slovanský. O životě a skutcích Keltů [Celtů] a Markomannů ve vlasti naší dějepis velmi ř́́dké, a to mlhou nejistoty a pochybností zahalené správy podává. O slovanském pokolení za pohanské doby ovšem již hojnější podání se vyskytují, avšak i tyto nejisté a na mnoze báječné jsou. Pročež archeologii české pohanské doby bedlivého historického badání a srovnávání na nejvýš potřebí.

A nenít na tom dosti, aby zpytatel národních starožitností pouze $\mathrm{k}$ dějinám národův evropejských zření své obracel; věc sama káže, aby historické zpytování rozšíril též k národům vzdálené Asie, zvláště k pradávným obyvatelům Indie, Persie a těm, jenž na břehách Pontinských obývali. Pole to zajisté ohromné, zvláště povážíme-li, že archeolog, jenž vniknouti chce do ducha starobylostí, též i k mythologii, národo- a jazykozpytu outočiště bráti musí, ano že jemu i třeba, k př́rodě, zvláště pak k lučbě zřetel svůj obraceti. Lučba nejpatrněji může ustanoviti, zdali kovová slitina z doby předkřestanské pocházející, výrobkem jest keltické [celtické], germanské neb slovanské ruky. Památky lidské činnosti, nalezené ve vrstvách mocí Neptunskou utvořených, nástroje a náčiní rukou lidskou zhotovené, avšak působením času v kámen obrácené, nutí nás, abychom zkoumající prř́rodovědě nálezy své na uváženou předložili, a na rozhodnutí takto získaná další zpytování svá stavěli a opírali.

Tak tedy znamenáme, že děje- a národopis, mluvozpyt i př́rodověda musí nápomocny býti archeologovi, zpytateli jenž pojav úlohu svou duchem vědeckým, věrně o to se zasazuje, aby pravdu nezkalenou z hlubokých tmavých bání pradávných věků na jasné denní světlo vyvedl.

\{Tím jedině zpytateli starožitností možnost se naskytuje, aby k líčení domácího a veřejného života, obyčejů, zákonů a náboženských obřadů netoliko slovanských Čechů, nýbrž i keltických [celtických] a německých praobyvatelů na půdě české přistoupil a takto látku k prahistorii vlasti naší přihotovil a sestavil. Prahistorie České země ovšem pouze během času důkladně se může vyvinouti; ját toliko v přednáškách tohoto půlletí chci material snášeti k tomuto cíli, a v systematickém pořádku jej s vámi, pp., sdíleti.

Chtěje poskytnouti alespoň zběžný přehled velkého jeviště, na němž se národní archeologie pohybuje, přistupuji k době křestanské. /... Další partie se zabývá „ostatky umění básnického, stavitelského, malírského a obraznického" - K. S./

Podav takto zběžný přehled obsahu archeologie české, ukázal jsem, jak nesmírné pole činnosti ona obsahuje, tak že jedinému člověku ani možno není, aby veškerým úkolům této vědy dosti učinil. Nebot' kdo může se honositi zevrubnou vědomostí národo- i zeměpisu, známostí dávných náboženských i společenských obřadů a obyčejů, i vědomostí tolika žijících i mrtvých jazyků? Kdož mimo to znatelem jest literatury středověké, i znatelem a posuzovatelem mincí, pečetí, obrazů a stavení rozličných věků a druhů? Kde se nalezá onen učenec, jenžby s těmito vědomostmi též i známost př́rodovědy spojoval a nad tímto ohromným obsahem věd kritickým duchem a jasným rozumem panujíc, na pravdě založené výsledky zpytování svého světu na odiv by postaviti mohl? Každý z vás, Pp., uzná, že život lidský, byt' i příroda sebe delší lhutu jemu vyměřila, nestačí $\mathrm{k}$ získání tak rozmanitých, tak rozsáhlých vědomostí, z nichžto každá s to jest, aby veškerou činnost důkladného zpytatele zaujala. Duch i př́roda nás zde na vzájemnost vědeckou odkazují. Tak jako posvátný cit národnosti $\mathrm{k}$ př́buzným národům víže nás a nutí, abychom z jich osudů, jazyka a duševních plodů posilu a prospěch vážili, - tak tomu i duch vědy chce, aby jedna u druhé rady a posílení hledala. -

Tu se však nejeden táže, jaký prospěch věda archeologická, k nížto sobě jen nevšedním namáháním klíče lze dobýti, pěstitelům svým poskytuje? Jen ten, kdo ve všední ledabylosti život trávě, k vyšší duševní ceně jeho zřetel neobrátil, jen takový může pochybovati o výhodách, ježto známost národní naší vědy přináší.\} Účel každé vědy býti musí, rozšiřovati vědomosti, tající se budto v ř́šsi př́rody, aneb v duševním životě člověčenstva. Nebudiž to na újmu př́rodovědě řečeno, když tvrdím, že stopy života [činnosti] pouhé přírody mnohem pečlivěji a nákladněji zpytovány byly až dosavad, nežli důkazy činnosti ducha lidského, (jevící se v ostatcích umění snahou a silou ducha zplozených. Ovšem zdá se, že zpytováním přírody a pouhé hmoty občanům i státu více hmotného prospěchu se získá, nežli snažením naším, jakož i snažením vědy vůbec, kterážto pouze duševní živel za předmět zpytování sobě obrala. Než však člověk netoliko hmotně, ale i duševně žije, a nespravedlivé a nehodné vyšší nadsmyslné hodnosti jeho bylo by, kdyby se pouze hojným nákladem pečovalo o zvířecí stránku člověka, kdežtoby se duch, jenž v nadsmyslné ŕíši věd pokrm, útěchu a ozdobu svou nalezá, potrava a posila taková za př́ćcinou zdánlivého materialního neprospěchu skoupě upírala. Namítati by se ovšem mohlo, že říše přírody podává v systematickém ústrojí svém obraz podivu hodného organismu, v němž se vyšší úmysl tvưrce zjevuje, kdežto o plodech lidské ruky z dávných časů nám dochovaných dle dosavadního mínění totéž tvrditi nelze. Avšak člověk jest nejskvělejším tvorem síly světoplodné, a v postupném vyvinování ducha lidského jeví se taktéž velebný úmysl věčného tvůrce. Rozumu zpytujícímu ostatně známo, že jedna věda, jedna pravda po druhé z lůna tmavé nevědomosti se vyvinuje. Vědecká pravda, dnes ještě v hustých mlhách budoucnosti se tající, o nížto tudíž ani nejmenšího tušení nemáme, může v příšs- 
tím věku snášeti se co jasná hvězda na obloze lidských vědomostí. Tak zajisté nepochybujeme, že kdyby asi před třemi sty léty někdo n. p. o systematickém nerostů ústrojí na hlatopisu založeném mluviti chtěl, rovněž by se s podobnou nedůvěrou potkal, jako ten, jenžby již nyní vědeckou soustavu ve hmotných starobylostí ostatcích snažil se dokázati. Nicméně předvídám, že v nedlouhém čase věda archeologická na onen stupeň se povznese, kde snadno bude, dle jistých určitých znaků a znamení ustanoviti věk, spůsob a národní původ archeologických předmětů, makavých to důkazů dávnověké činnosti ducha lidského!

Archeologií českou rozšiřuje se zajisté známost duševní činnosti člověčenstva a sice té částky člověčenstva, s kteroužto my Čechové krví i duchem nejblíže spř́ízněni jsme.\} Věda tato nás učí znáti vyšší mravní cenu lidu českoslovanského, ona stopuje kroky národa na cestách života jeho od těch dob, co se ze stavu př́rody vyvinul, po všech stupních jeho zdokonalování; ukazujet' ovšem i na poklesky a zpáteční kroky, které bud'to vlastní nebo cizí vinou puzen jsa, národ na dráze této učinil. Poskytuje tedy věda naše zdroje světla vědeckého a spolu i prameny útěchy, národní lásky a důstojnosti, jakož i \{prameny vyššího\} naučení, opatrnosti a tudíž i občanské moudosti, a takto bohdá! věda naše přispívati bude $\mathrm{k}$ uvědomění a a ušlechtění mladého čechoslovanského pokolení, jehožto úlohou jest, [na nižto úloha připadá,] aby vytrvale a trpělivě pracujíc, nestranností \{, spravedlivostí\} a vědeckou i mravní jadrností svou národnost českou před \{veškerým\} světem k vyšší důstojnosti a velebnosti povzneslo. -

Konečně \{Pánové moji! nucena se cítím podotknouti, že já zde význam, objem, obsah a úkol české archeologie tak jsem líčil, jak vroucně přeji, aby věda tato ve vlasti naší pěstována a zvelebována byla. Daleko jsem však toho mínění vzdálen, žeby schopnosti, vědomosti a síly mé k vykonání takovéto úlohy dostačovaly; já toliko výsledky a zkušenosti, které - láskou k historické velebnosti národa českého veden jsa - za minulých časů dosti pracně jsem získal, zde míním přednášeti, k tomu hledě, abych náhledy, které v duchu mém se utvořily, dle možnosti v soustavní pořádek uvedl. Než však s citem vděčnosti vyznávám se, že v přednáškách svých se opírám hlavně na pevný základ, jejžto mi slovutní učenci naši Palacký a Šafařík ve spisech svých položili. Šafař́k kovy Starožitnosti, kniha to neocenitelná, posvátná všem slovanským národům, musí mi býti pravidlem a vůdcem, kdekoli předmět můj do říše národopisu a do dějin staroslovanských zabíhá. Nebudiž vám tedy divno, Pánové! jestli začasto se známými od jinud správami se potkáte. Kdyby Šafař́kova díla nebylo, s těžkostí bychom pravé cesty nalezli v dávnověkosti slovanské, hustou temnotou zatajené, a já bych sotva se s Vámi Pánové vydati mohl na cestu do pradávných věků vlasti naší. Na základě, slavnými badateli našimi položeném, chci tedy dle skromné síly své stavěti, té pevné naděje jsa, že mnohý z Vás, Pánové! dále bude zvelebovati vědu, v nížto národ náš minulý svůj život spatří a z pohledu takového útěchu, naději, sílu a občanskou moudrost vážiti bude! -\}

/Marg. v rkp.: Účel arch. č. doby předkřestanské jest, život, mravy a spůsoby těch národů líčiti, kteří v době předkřestanské ve vlasti naší české přebývali./

\section{Příloha 9. \\ Jan Erazim Vocel: Programový úvod k přednášce o archeologii křestanského stř̌edověku (přednesen 6. 11. 1850) 15}

\section{Appendix 9. \\ Jan Erazim Vocel: Programme introduction to the lecture on the archaeology of the Christian Middle Ages \\ (delivered on 6 November 1850)}

a/Wocel, f. E. 1850b: Česká archeologie křestanského středověku. Časopis Národního muzea 24, 541-555.

b/Totéž, separátní tisk. Praha 1850, 18 str. /Kráceno./

Archeologie /.../ dle novějšího pojmu jest nauka, která pomocí starobylých památek osvětluje život národů. Nauka tato jedná o starobylém umění, taktéž o mincích, nápisech, obrazech historických, obsahuje známost obřadů náboženských, starodávních zákonů. obyčejů a spůsobů domácího i veřejného života. Již z toho na jevě jest, jak nesmírné pole zpytování nauka tato otvírá. Ještě znamenitěji však šíři se pole toto, když pová-

$15 \mathrm{~V}$ tomto př́padě jde $\mathrm{u} / \mathrm{b} /$ o přímý separátní otisk článku v Časopise Národního (tehdy Českého) muzea; vzhledem k jeho dostupnosti jsou zde uvedeny pouze výňatky. 
žíme, že každý národ, který za minulých věků nějakého stupně vzdělanosti dosáhl, svou zvláštní archeologii má, která opět na mnohé větve rozdělena jest. /.../

Nauka o dávném životě národů nynějš́ích sluje archeologií národní, kdežto nauka o starobylostech dávno zahynulých klassických národů archeologii klassickou se nazývá.

Poněvadž každý vzdělaný národ svou vlastní archeologii má, /.../ protož i my Čechoslované zavázáni jsme citem vděčnosti a lásky $\mathrm{k}$ předkům svým, abychom zřetel k ostatkům jich vzdělanosti a duševního života obraceli.

O starožitnostech českých předkřestanské doby jednal jsem v minulém půlletí; předmětem přednášek, ježto dnes začínám, jest archeologie česká křest'anského středověku.

Účel české archeologie krestáanského středověku jest, pomocí starobylých památek utvoriti pravdivý obraz života Čechüv ve středním věku. /.../

Čím vzdálenější doba, o nížto dějepis jedná, tím důležitější, tím vážnější jest zpytování archeologické. Ano tvrditi můžeme, že v nejdávnější předkřestanské době vlasti naší archeologické zpytování zaujímá přední místo, kdežto dějepis do zadu ustupuje. Nebot' zdroje historické věku celtického, markomanského a pohanskoslovanského tak sporé jsou a nevydatné, že se v krátkém čase mohou sčísti a během několika hodin úplně přehlédnouti, kdežto svědectví archeologické pomocí srovnávající methody z dávných dob vážená tak hojná jsou, že by ne hodin několik, nýbrž celých let k úplnému se s nimi seznámení potřebí bylo. /.../To co dějepis jako v mlhách tahy všeobecnými naznačuje, nabývá těla, podstaty, individualnosti. Zde pokolení dávno zhaslá a zapomenutá mluví $\mathrm{k}$ zraku, $\mathrm{k}$ citu našemu prostředkem památek ze země, z rumu, z mohyl dobytých. Tu zbraň, tam mince, zde ohrada, tu nádoba, tam žaroviště poskytuje zřejmé svědectví o vzdělanosti, řemeslnické zběhlosti, domácím životě a obřadu náboženském i pohřebním; jména míst, vrchů a potoků zvučí až posud starodávním původním hlaholem $\mathrm{k}$ sluchu našemu a starobylá báseň a pověst zbuzuje v duchu a srdci ozvěnu myšlének, citů a toužení oněch pokolení, o nichžto dějepis bud'to žádné, budto zběžné a nejisté zprávy podává.

Avšak ve stř̌edním věku popouští archeologie znenáhla přední místo vědě té, která pravdivé, pamětihodné události a děje z pramenů písemních a z ústního podání vážené, popisuje, t. j. dějepisu. /.../ Historie a archeologie tudíz $i$ ve středním věku úzce spojeny býti musí, aby úplný všestranný pohled na minulé doby národu našeho poskytnouti mohly.

/Další text se týká již výhradně dějin středověkého umění. Na závěr připojuje Vocel rozvrh svých výkladů $\mathrm{v}$ rámci této přednášky./

1. Všeobecný přehled dějů a vzdělanosti evropských národů ve středním věku.

2. Nástin dějů českých a líčení vzdělanosti Čechův ve středním věku.

3. Počátky a spůsob vyvinování umění křestáanského vůbec.

4. Umění v Čechách za křestanského středověku a památky jeho až dosavad zachované, a sice:

A. Národní doba českého umění až do polovice XIII století sahající: a) stavitelství, b) obraznictví, c) básnictví.

B. Druhá doba českého umění až k bitvě bělohorské sahající.

\section{Anfänge des Universitätsunterrichts der nichtklassischen Archäologie in Programmansprachen von Jan Kollár und Jan Erazim Vocel (1849-1851).}

\section{Zusammenfassung.}

Nach den vereinzelten Versuchen, die „heimische“ Archäologie in europäische Universitäten einzuführen (J. G. G. Büsching in Breslau 1816 ff.) und nach der relativ kurzen Existenz des ersten offizialen Lehrstuhls solcher Archäologie in Leiden (C. J. C. Reuvens, 1818-35) wurde der regelmäßige Universitätsunterricht der nichtklassischen Archäologie zum erstenmal in der österreichischen Monarchie eingeführt: im Jahre 1849 in Wien und 1850 in Prag. Diese beiden gleichlaufenden Fälle wurden durch die politischen Verhältnissen nach dem stürmischen Jahr 1848 beeinflußt.

Eine außerordentliche Professur der slawischen Altertümer wurde im J. 1849 an der Wiener Universität - als Belohnung des Poeten Jan Kollár (1793-1852) für die der Wiener Regierung in der Zeit der ungarischen Revolution erwiesene Dienste - errichtet. Es war eher ein Ehrenamt, das Kollár nur während kurzer Zeit bekleidete, er ist schon im Jahre 1852 gestorben. Als ein unkritischer Romantiker und Dilettant hat er für die Wissenschaft nichts Neues gebracht - er hat sich vor allem den (gefälschten) „Idolen von Rhetra" in Mecklenburg und der vermeintlichen urslawischen Besiedlung Italiens gewidmet, an die er fest glaubte. Seine Professur ist aber zu einem Präzedenzfall geworden, der es erlaubte, an ein ähnliches Amt auch außerhalb der Hauptstadt des Reiches zu denken. Dank seiner Teilnahme in einer informellen „Regierungspartei“ der konservativen Patrioten nach der Revolution des Jahres 1848 in Böhmen wurde Jan Erazim Vocel (1802-1871) 1850 zum außerordentlichen, 1862 dann zum ordentlichen Professor mit der Spezifikation für die tschechische (später allgemeine) Archäologie und Kunstgeschichte ernannt. Im April 1850 hat er mit einer Vorlesung über die „heidnische Vorzeit" Böhmens begonnen. Später hat er auch die mittelalterlichen Altertümer (einschließlich des frühen Mittelalters) und die Kunstgeschichte, klassische Archäologie $u$. a. vorgetragen. Mit ihm ist endlich und definitiv die wirkliche Archäologie in beiläufig heutigem Sinne den Universitätsboden betreten.

Dieser Beitrag soll einige erhaltene handschriftliche Texte der Eröffnungs- und Abschlußreden zu den Vorlesungen von J. Kollár (aus den Jahren 1849-51) und J. E. Vocel (1850) zugänglich machen; es sind dies interessante Dokumente nicht nur für den sachlichen Inhalt der Vorle- 


\section{ÒnShí ARCHITOLOGIR \\ křesfanského středovèku.}

\section{Úvodni čtení}

přednešeno

dne 6. Listopadu 1850 na universitě Pražské.

Od

J. L. Wocela,

c. kr. mimor̀. profesora archeologie c̀eské a historie umèní.

\section{PRAZE 1850.}

TISKES K. JEǨábKOVÉ, ŘízeNíM J. HLAVÁČča.

Obr. 9. Separátní tisk Vocelova úvodu k přednášce o křestáanské archeologii z 6. 11. 1850. - Fig. 9. Separate print of Vocel's introduction to the lecture on Christian archaeology from 6 November 1850.

sungen, aber auch für das Erkennen des unterschiedlichen Charakters der beiden ersten Professoren, deren Zutritt und Auffassung der Themen; das Zeugnis vom Wesen der Anfängen der Universitätsarchäologie sowie ein Beitrag zur Fachgeschichte.
Karel Sklenář

Vinohradská 34

12000 Praha 2

email: zuzana.blahova@ff.cuni.cz 